From volume 129-1 (2014) onward, a compilation of book reviews per volume is published as pdf file at www.bmgn-lchr.nl.

Vanaf aflevering 129-1 (2014) wordt een compilatie van de boekbesprekingen per aflevering gepubliceerd als pdf bestand op www.bmgn-lchr.nl. 
Tycho Walaardt, Geruisloos inwilligen. Argumentatie en speelruimte in de Nederlandse asielprocedure 1945-1994 (Dissertatie Leiden 2012, Historische migratiestudies 1; Hilversum: Verloren, 2012, 414 pp., ISBN 978908704294 3); Corrie van Eijl, Tussenland. Illegaal in Nederland 1945-2000 (Historische migratiestudies 2; Hilversum: Verloren, 2012, 244 pp., ISBN 978908704303 2).

Deze beide boeken behandelen aspecten van het Nederlandse naoorlogse vreemdelingenbeleid. Tycho Walaardt levert met dit boek de handelseditie van zijn proefschrift. Corrie van Eijl heeft zich reeds verdienstelijk gemaakt in het historisch migratieonderzoek met een analyse van het Nederlandse toelatingsbeleid tussen 1840 en 1940 in Al te goed is buurmans gek (2006).

Walaardt en Van Eijl gaan vooral in op de kloof tussen doel en uitkomst van het beleid. De discussie over deze kloof werd in de academische literatuur gelanceerd door de Amerikaanse politicoloog James Hollifield. Hij wees tijdens de jaren tachtig op de liberale waarden van het West-Europese politieke bestel als morele rem op een effectief vreemdelingenbeleid. Walaardt en Van Eijl gaan niet expliciet de discussie aan met Hollifield, maar wijzen er met name op dat de orde die het toelatingsbeleid voorstond in de praktijk heel wat chaotischer was dan de beleidsmakers lieten uitschijnen. Zo wijst Walaardt erop dat de vluchtelingenerkenning op basis van de Conventie van Genève de illusie bood dat er harde grenzen te trekken waren tussen zij die bescherming nodig hadden (de vluchtelingen) en de andere ongenode nieuwkomers. Deze juridische realiteit vindt hij in zijn onderzoek niet terug in de sociale realiteit: slechts weinigen werden erkend als Conventievluchtelingen, terwijl vele andere asielzoekers toch in Nederland konden blijven. Van Eijl laat zien dat er altijd immigranten geweest zijn zonder verblijfspapieren en dat hun verwijdering allesbehalve probleemloos verliep. Het naoorlogse vluchtelingenbeleid kreeg eerder aandacht in de publicaties van Corrie Berghuis over de periode 1945-1956 en van Willem ten Doesschate voor 1968-1982. Het beleid ten aanzien van mensen zonder papieren was, afgezien van het onderzoek van Groenendael naar regularisatieoperaties (1975-1985), nog niet onderzocht. Van Eijl put hier uitvoerig uit voor die periode. Het vernieuwende van de publicaties van Van Eijl en Walaardt is dat ze het beleid van Justitie diepgaander analyseren. Beide boeken steunen vooral op beleidsdossiers in de archieven van met name de Immigratie- en Naturalisatiedienst (IND). 
Walaardt heeft deze traditionele archivalia van de politieke geschiedenis aangevuld met 500 dossiers van individuele asielzoekers. Deze individuele dossiers vormen zijn toegangspoort tot het effectieve toelatingsbeleid voor asielzoekers. Met de diepteanalyse van deze dossiers kan hij nagaan of mensen bescherming werd geboden als vluchteling of dat ze het moesten stellen met een zwakkere verblijfsstatus, het land moesten verlaten of zelfs hardhandig uit Nederland werden verwijderd. Uit dit arbeidsintensieve onderzoek blijkt dat slechts weinig asielzoekers als vluchteling werden beschouwd. De afgewezen asielzoekers moesten Nederland in principe verlaten. Evenwel blijkt dat zij tot de jaren zeventig toch konden blijven in Nederland als ze bereid waren arbeidsmarktnoden te lenigen. Nadien riep de overheid eerder humanitaire overwegingen in om afgewezen asielzoekers toe te laten. Vanaf de asielcrisis van de jaren tachtig bouwde Justitie het beeld van een strenge overheid op, maar dat was, volgens de auteur, slechts papieren machtsvertoon. Het beeld van een strenge overheid die de toegang tot Nederland bewaakte had, volgens de auteur tot doel nieuwkomers af te schrikken.

Walaardt steunt zijn beeld van de overheid als een papieren tijger op de resultaten van een steekproef, waaruit blijkt dat ruim zeventig procent van de asielzoekers uiteindelijk kon blijven. Dit is een steekproef uit de nog bewaarde dossiers van etnische groepen die in relatief belangrijke getallen naar Nederland zijn gekomen (Iraniërs, christelijke Turken, Eritreërs, Tamils uit Sri Lanka). In 1987 werd besloten de asieldossiers van uit Nederland vertrokken vreemdelingen waarvan het dossier aangeeft dat er nauwelijks debat was geweest, te vernietigen. De asielzoekers die het uitwijzingsbevel opvolgden na een asielweigering zijn logischerwijze niet in de steekproef terug te vinden. Walaardts conclusie is dus niet gebaseerd op een voor de behandelde periode representatieve steekproef van asielzoekers, maar geldt alleen voor de halsstarrige blijvers onder de uitgeprocedeerde asielzoekers uit kwantitatief belangrijke etnische groepen. De auteur onderzoekt waarom hun verzoek werd ingewilligd. De nietuitzetbaarheid van deze asielzoekers was mede bepaald door hun langdurig verblijf in Nederland, dat hen in staat stelde een sociaal netwerk uit te bouwen dat ze konden mobiliseren voor hun uiteindelijke toelating. Het beleid ging pragmatisch om met deze koppige blijvers, wat leidde tot een verruiming van het toelatingsbeleid. De literatuur stelt dat deze kloof tussen beleid en praktijk het gevolg was van verschillende beleidsvisies of de interventie door de rechterlijke macht, maar Walaardt kent meer autonomie toe aan de IND. Hij spreekt van een geruisloze inwilliging: individueel en op administratieve wijze kregen deze afgewezen asielzoekers een humanitaire status met minder rechten dan de vluchtelingen.

Via de persoonlijke dossiers poogt Walaardt ook het maatschappelijk debat te reconstrueren. Deze persoonsgebonden invalshoek levert uitspraken op van overheid, media en politici over asielzoekers. Volgens Walaardt representeren degenen die hun mening uitten in de brieven en publicaties die hij terugvond in de persoonsdossiers het Nederlandse volk, maar dit had op een andere wijze gekwalificeerd kunnen worden. 
Het boek van Van Eijl behandelt vreemdelingen in Nederland zonder verblijfsvergunning. Het betreft zowel mensen die zonder toestemming van de overheid Nederland binnenkomen, als mensen die rechtmatig het land binnenkomen, maar wier verblijfspapieren na verloop van tijd niet worden verlengd (bijvoorbeeld uitgeprocedeerde asielzoekers). Van Eijl spreekt van een 'tussenland' voor mensen met een niet erkende aanwezigheid in Nederland. Over een periode van 55 jaar onderzoekt zij om welke mensen het ging en gaat. Tussen 1945 en 2000 onderscheidt zij drie regimes: het postkoloniale, het gastarbeiders- en het asielmigratieregime. Het overheidsbeleid was er steeds op gericht de inwoners uit het 'tussenland' te verwijderen, maar de intensiteit van die overheidsinzet wijzigde zich ingrijpend tijdens de drie migratieregimes.

Tijdens het postkoloniale migratieregime werden de inwoners van 'tussenland', op de communisten na, nauwelijks geproblematiseerd. Vanaf de jaren zestig veranderde dit. De overheid beoogde mensen zonder papieren aan te zetten het land te verlaten, maar door verzet van deze immigranten, al dan niet ondersteund door actiegroepen, verliep dit allesbehalve vlot. Het hardhandig verwijderen van ongewenste immigranten stootte ook op financiële, politieke en diplomatieke grenzen. Andere actoren werden te hulp geroepen: degenen die deze immigranten tewerkstelden werden gedwongen de verwijdering van hun werknemers mee te financieren en in de jaren negentig werden de (transport)ondernemers die deze immigranten naar Nederland hadden gebracht verantwoordelijk gesteld voor hun verwijdering. Verwijdering werd ook steeds meer een thema binnen diplomatieke onderhandelingen, maar ondanks alle investeringen bleef het succes van het verwijderingsbeleid beperkt.

Daarnaast was gedogen ook onderdeel van het instrumentarium van de overheid. Tijdens het gastarbeidersmigratieregime werd, gezien de grote nood aan arbeidskrachten, niet zo zwaar getild aan immigranten die zich zonder vergunning ophielden in Nederland. Dit verklaart de aangroei van de bevolking van het 'tussenland', maar op het einde van het gastarbeidersregime traden veel Turken en Marokkanen die door hun (geregistreerde) arbeid hadden bijgedragen tot de Nederlandse welvaart toe tot het officiële Nederland. Tot in de jaren tachtig en negentig bleef Nederland expliciet mensen zonder verblijfspapieren gedogen. Het betrof toen vooral asielzoekers die niet erkend werden als (Conventie-)vluchtelingen, maar waarvan repatriëring gezien de onveilige situatie in het land van herkomst of vanwege technische redenen moeilijk was. Ook heel wat van deze gedoogden werden na verloop van tijd geregulariseerd.

Regularisatie werd beschouwd als het toedekken van een coulanter beleid op het moment dat de overheid overging tot een verstrakking van dat beleid. Vreemdelingen die in Nederland verbleven en werkten, bijstand of gezondheidszorg ontvingen, werden steeds nauwgezetter centraal geregistreerd. Dit proces legde de contradicties binnen het overheidsoptreden bloot: Justitie was de aantrekker in de verstrakking van het verwijderingsbeleid, maar had medewerking nodig van Sociale Zaken die economische en humanitaire noden centraal stelde. Justitie slaagde er gedurende de behandelde periode in om steeds meer greep te krijgen op het beleid en de invloed van andere nationale 
beleidsactoren en beleidsniveaus af te zwakken. Deze beleidsdynamiek wordt voortreffelijk aangetoond met het beleid ten opzichte van illegale Chinezen (1955-1975), dat een breed panorama biedt met aandacht voor heel wat actoren in Nederland bij dit migratieproces. Jammer genoeg blijven de Chinese, maar ook de Belgische overheid (België verleende blijkbaar de visa) uit beeld, wat een zwakte van dit onderzoek aangeeft: namelijk enkel steunend op Nederlands bronnenmateriaal. In het migratie-onderzoek is een nationaal perspectief ontoereikend, aangezien migratie een transnationaal fenomeen bij uitstek is. Ook bij onderzoek naar het beheer van migratie is een transnationale blik een meerwaarde.

Zowel Walaardt als Van Eijl heeft weinig aandacht voor andere politieke actoren dan Justitie. Bij Walaardt leidt dit zelfs tot een weglating van de beleidsontwikkelingen. De invloed van de rechterlijke macht en het UNHCR, die beide het Nederlandse vluchtelingenbeleid meebepaalden zoals Ten Doesschate aangaf, komt nauwelijks aan bod. Dat Walaardt de autonomie van de IND zo centraal stelt in zijn conclusies lijkt dan ook een gevolg van de gereduceerde institutionele setting waarbinnen hij het beleid analyseert.

Vernieuwend is de aandacht van beide auteurs voor taalhandelingen. Walaardt analyseert systematisch het vertoog bij asielverzoeken aan de hand van zeven frames: vrees voor vervolging, geloofwaardigheid, aantallen, kritiek op de asielprocedure, medemenselijkheid, de persoon van de asielzoeker en tenslotte kosten en baten. Een interessante observatie is hoe de Koude Oorlog-retoriek - in het kielzog van de 'ontdekking' van de Holocaust - overgaat in een discours van mensenrechten. Van Eijl besteedt uitvoerig aandacht aan de beleidsretoriek. Zij concludeert dat mensen zonder papieren tijdens de naoorlogse periode in een lineair proces van stigmatisering, discriminering en criminalisering tot een steeds meer geviseerde bevolkingsgroep werden. De auteur brengt dit samen onder de noemer illegalisering van migranten.

Van Eijls studie is een uitstekend overzicht van de beleidsdynamiek binnen Nederland tussen 1945 en 2000. Ze geeft aan dat het verharden van het discours rond de inwoners van het 'tussenland' het beleid heeft aangezet tot een quasi zerotolerantie van deze migranten in het begin van de eenentwintigste eeuw. Van Eijls historische analyse laat zien dat dit een te hooggespannen beleidsambitie is. Zij besluit dat het 'tussenland' niet zozeer ontstaat en groeit door het verlies van controle over migratie, maar eerder door de fictie dat het opdrijven van controle een zo complex fenomeen als migratie kan beheersen. Walaardt heeft het naoorlogse asielbeleid onderzocht met een nadruk op de verruiming van het humanitaire beleid en het maatschappelijk debat. Een erkenning als Conventie-vluchteling blijkt slechts de ere-toegang te zijn, andere asielzoekers moesten lang aandringen om toegang te krijgen tot Nederland via de achterdeur.

Frank Caestecker, Universiteit Gent 
Bart Leeuwenburgh, Het noodlot van een ketter. Adriaan Koerbagh 1633-1669 (Nijmegen: Vantilt, 2013, 262 pp., ISBN 978946004114 3).

Het noodlot van een ketter biedt een mooie, leesbare inleiding tot het leven en werk van een van de meest radicale publicisten uit de zeventiende eeuw, de Amsterdamse arts en jurist Adriaan Koerbagh. Koerbagh, vooral bekend vanwege zijn banden met de groep vrijdenkers rond Spinoza, rijst op uit Leeuwenburghs biografie als een gedreven polemist die de nieuwe wetenschappelijke cultuur van zijn tijd probeerde te vertalen in doelgericht maatschappelijk engagement. Meegezogen door de rationalistische en religieuze stroomversnellingen in de Republiek in het kielzog van Descartes en de collegianten, overspeelde Koerbagh echter zijn hand en werd hij als kop van jut geslachtofferd door de Amsterdamse schepenbank. Met Koerbaghs veroordeling in 1668 tot tien jaar Rasphuis werd pijnlijk duidelijk dat de officieel beleden 'ware vrijheid' van het stadhouderloze regime onder Johan de Witt strenge grenzen kende.

Leeuwenburgh, verbonden aan de Faculteit Wijsbegeerte van de Erasmus Universiteit, stelt zich nadrukkelijk de vraag hoe het te verklaren is dat dit vonnis geveld werd in de juist om haar tolerantie geroemde Nederlandse Republiek. Om hierop een antwoord te geven maakt hij dankbaar gebruik van het al verrichte onderzoek naar Koerbagh, met name het pionierswerk van de laat negentiende-eeuwse vrijdenker Koenraad Oege Meinsma (Spinoza en zijn kring) en de recente Engelstalige studies van Michiel Wielema, die Koerbagh ook internationaal meer bekendheid hebben gegeven. Veel nieuw (archief)onderzoek bevat Het noodlot van een ketter niet: het gaat Leeuwenburgh om het opstellen van een synthese van de al bestaande interpretaties. Daarin slaagt hij ten dele. In zijn prijzenswaardige poging Koerbagh grondig te situeren in zijn tijd vervalt Leeuwenburgh nog wel eens in het oplepelen van wijdlopige contextuele informatie, waardoor de biografie wat traag op gang komt. Wat niet helpt, is dat Leeuwenburgh daarbij regelmatig meent zijn toevlucht te moeten zoeken tot platitudes door te benadrukken dat alles in de zeventiende eeuw toch zo anders was dan in ons huidige tijdsgewricht: een overdreven knieval voor de niet-ingewijde lezer waardoor de hoofdlijn van het boek enkel uit zicht verdwijnt. Koerbaghs eigen schrijfsels blijven daarom wat onderbelicht, en pas tegen het eind van het boek komen zijn ketterse ideeën echt ter sprake. Maar ook daar wordt niet altijd duidelijk wat nu precies de kern was van Koerbaghs denken. Door in meer detail en met meer methodologische finesse te 
analyseren wat Koerbagh nu eigenlijk schreef, tegen wie, en op welke manier, had Leeuwenburgh daadwerkelijk nieuw licht kunnen werpen op de intellectuele merites van deze noodlottige ketter.

Leeuwenburgh is duidelijk meer in zijn element in een aantal rake typeringen van belangrijke bijfiguren in het boek, zoals Descartes, en in zijn gedegen schets van de verschillende werelden die bij Koerbagh samenkomen: de wereld van de postcartesiaanse wetenschap, de praktische geneeskunde in Leiden, en de lexicografie waarin Koerbagh uiteindelijk zou schitteren als auteur van het zeer gewaagde woordenboek Een Bloemhof van allerley lieflykheyd sonder verdriet. Bovendien geeft Leeuwenburgh overtuigend aan, ook hier in het voetspoor van Wielema, hoe Koerbagh met zijn publieke engagement en vertrouwen in ieders rationele vermogens verschilde van de meer 'verheven', afstandelijk schrijvende Spinoza. Waar Spinoza 'de godsdienstige en politieke realiteit van de Republiek als illustratie opvoerde ter ondersteuning van zijn in principe tijdloze abstracte betoog', daar stond bij Koerbagh 'de theorie juist in dienst van de politieke realiteit', aldus Leeuwenburgh. 'De theoretisch-filosofische vooronderstellingen moesten worden ingezet om de maatschappij te veranderen' (132). Koerbagh treedt zo vanuit de lange schaduw van Spinoza naar voren als misschien wel de meest radicale auteur van de vroege Nederlandse Verlichting - en het is Leeuwenburghs belangrijkste verdienste dat hij Koerbagh hiermee op nuchtere wijze beoordeelt op zijn eigen historische betekenis.

Het boek eindigt, natuurlijk, met het meeslepende relaas van Koerbaghs vlucht naar de vrijhaven Culemborg, van de drukker die hem verraadde en de intriges van de mysterieuze 'man met het dassie', tot de uiteindelijke arrestatie van Koerbagh in Leiden en zijn proces in het Amsterdams stadhuis. Om zijn hoofdvraag te beantwoorden, geeft Leeuwenburgh een aantal plausibele verklaringen voor de hoge straf die Koerbagh daar hoorde eisen: de strenge anti-sociniaanse plakkaten van 1653 en 1656, het feit dat Koerbagh schreef met scherpe pen - in het Nederlands en bovendien onder eigen naam -, zijn vrijzinnige gedrag en uitdagende optreden, de veranderende machtsbalans onder de Amsterdamse regenten, de constante frictie tussen het stadsbestuur en de kerkelijke orthodoxie. Alle bij elkaar afdoende factoren om Koerbaghs veroordeling te verklaren.

Wat echter opvalt, is dat Leeuwenburg hier weinig zegt over de juridische context: hoe bijzonder was Koerbaghs lot nu eigenlijk in de zeventiende eeuw? Wat was de jurisprudentie omtrent dit soort intellectuele overtredingen? Welke rol speelde de politieke en juridische decentralisatie van de Republiek in het handhaven van de rechtsorde? Koerbaghs vlucht naar Culemborg en de onderhandelingen omtrent zijn arrestatie tussen Amsterdam en Leiden doen vermoeden dat een zeventiende-eeuwse vrijdenker veel profijt kon hebben van de elkaar beconcurrerende jurisdicties van alle gewesten, steden en heerlijkheden die samen de lappendeken vormden van de Republiek. Tegelijkertijd zegt het feit dat hij uiteindelijk wel opgepakt werd, en veroordeeld, wellicht iets over de gestage ontwikkeling van een grensoverschrijdend rechtsstelsel. Maar daar schrijft Leeuwenburgh niet over, wat verbaast gezien zijn expliciete doelstelling 
Koerbaghs veroordeling te duiden binnen het clichébeeld van de Republiek als vrijplaats voor andersdenkenden.

Wat Leeuwenburghs studie niettemin wel mooi laat zien, is dat die vrijplaats van de Republiek - hoe clichématig het beeld ook - als broedvijver fungeerde voor soms de meest kleurrijke individuen en hun exorbitante ideeën en verstrekkende ideologieën, met constant hoogoplopende maatschappelijke, politieke en religieuze spanningen tot gevolg. Nu figuren als Koerbagh uit de schaduw treden van Spinoza, en daarmee ook nuttige kanttekeningen geplaatst worden bij Jonathan Israels baanbrekende Radical Enlightenment (2001), is het moment daar om dat rijke geestesleven van de Nederlandse zeventiende eeuw in al zijn bonte facetten verder voor het voetlicht te brengen.

Arthur Weststeijn, Koninklijk Nederlands Instituut te Rome 
Wilma van Giersbergen, Rotterdamse meesters. Twee eeuwen kunstacademie in

Rotterdam 1773-1998 (Leiden: Primavera Pers, Rotterdam: Gemeentearchief, 2012, 239 pp., ISBN 978905997120 2).

Wie tegenwoordig een kunstenaar of kunstwerk 'academisch' noemt, bedoelt dat niet waarderend. Dit is het gevolg van ontwikkelingen in de beeldende kunst gedurende de negentiende en twintigste eeuw, toen zelfverklaarde vernieuwers hun vooruitstrevende meesterwerken plaatsten tegenover 'zielloos productiewerk' van academische makelij. Het kan vreemd lopen. Tussen 1760 en 1800 werden in veel Nederlandse steden, zoals in Rotterdam, tekengenootschappen en -academies opgericht. Dit waren instanties waar nieuwe ideeën over de vervaardiging en functie van kunst werden ontwikkeld, uitgewisseld en in praktijk gebracht. Gearriveerde schilders oefenden zich er's avonds in het tekenen naar naakt model, leerling-kunstenaars en jonge ambachtslieden kregen er tekenonderwijs en liefhebbers ontwikkelden er hun smaak, om een beter mens te worden, maar ook om oordeelkundig - liefst Nederlandse - kunst te kunnen verzamelen. Dergelijke tekengenootschappen speelden een belangrijke rol in de eigentijdse behoefte gezamenlijk de cultuur én de economie van het vaderland tot nieuwe bloei te brengen. Kunstenaars leerden er kunst maken die aantrekkelijk was voor buitenlandse kopers. Ambachtslieden ontwikkelden er dankzij het tekenonderwijs een goede 'hand' en smaak, om via beter vormgegeven producten de vaderlandse export te helpen bevorderen. leder die kunst en vaderland een warm hart toedroeg, wilde deel uitmaken van één of meer tekengenootschappen.

Alle tekenaars volgden hetzelfde onderwijs. Men ging ervan uit dat het leren tekenen van de naakte mens volgens klassieke schoonheidsnormen, tenslotte het summum van schoonheid, voor iedere doelgroep het volmaakte basiscurriculum bood. Behalve tekenen werd er meestal onderwijs gegeven in anatomie, proportieleer en perspectief. Er werden redevoeringen gehouden over de vervaardiging van kunst en over esthetiek. Veel tekenacademies verwierven ter ondersteuning van het onderwijs schilderijen, tekeningen en vooral een collectie gipsen kopieën naar antieke beelden. Sommige organiseerden tentoonstellingen. Meestal waren er jaarlijkse prijsvragen voor leden, die prijzen wonnen voor tekeningen naar model of voor kunstwerken met een opgedragen onderwerp. Er waren avonden met zogeheten kunstbeschouwingen, waarbij tekeningen of prenten van de academie zelf, van zogenoemde ereleden of 
kunsthandelaren aan tafel rondgingen en werden voorzien van uitleg. De kosten van de academies werden gedragen door welgestelde leden die zo een vorm van maecenaat beoefenden en soms door de gemeentelijke overheid. De leden kwamen meestal uit de stad van vestiging; een landelijk kunstbeleid bestond er gedurende die eerste decennia niet. In tekenacademies kwamen allerlei verlichte idealen betreffende de functie van 'schone' kunsten, goed onderwijs, opvoeding, stimulering van industrie en nijverheid en dergelijke samen. Het moeten stimulerende gezelschappen zijn geweest. Diverse kunstacademies van tegenwoordig komen voort uit een achttiende-eeuws tekengenootschap.

Zo'n overzichtje in vogelvlucht valt voor vrijwel iedere periode tussen toen en nu te geven. Het moge duidelijk zijn dat de geschiedenis van het geïnstitutionaliseerde kunstonderwijs in Nederland niet alleen inzicht biedt in de opleiding van jonge kunstenaars, maar ook in het eigentijdse culturele en sociaal-economische leven, inclusief de relatie tussen opleiding en arbeidsmarkt. Vanzelfsprekend hebben er gedurende ruim twee eeuwen ingrijpende veranderingen bij kunstacademies plaatsgevonden. Die zijn goed te volgen in het boek dat Wilma van Giersbergen publiceerde over de geschiedenis van de Rotterdamse kunstacademie, vanaf de oprichting van het tekengenootschap 'Hierdoor tot Hooger' door vijf toonaangevende kunstenaars in 1773 tot de Willem de Kooning Academie en het Piet Zwart Instituut van nu. Het is een omvangrijke, mooi uitgegeven publicatie, boordevol 'nieuwe' afbeeldingen. De auteur, werkzaam bij het Stadsarchief in Rotterdam, schrijft over ontwikkelingen rondom een lokale instelling, maar deze geschiedenis is tegelijkertijd de geschiedenis van het Nederlandse kunst- en nijverheidsonderwijs, vol verbindingen met contemporaine sociaal-economische ontwikkelingen. Van Giersbergen heeft de geschiedenis van de academie in vier perioden ingedeeld en volgt per periode de ontwikkelingen op het gebied van organisatie en onderwijs op de voet. In het tijdvak 1773-1851 groeide uit 'Hierdoor tot Hooger' de Academie van Beeldende Kunsten en Technische Wetenschappen. Tussen 1851 en 1902 werd dit de eerste academie in Nederland waar kunst en technologie expliciet werden gecombineerd. Dit had te maken met de steeds verder toenemende mechanisatie in het industriële proces. Ornamenten werden meer en meer mechanisch geproduceerd. Ontwerp en productie waren niet langer in de hand van dezelfde persoon.

Er kwamen gespecialiseerde ontwerpers die op hen toegesneden onderwijs nodig hadden. Langzamerhand werd de kunstnijverheid prominent in het onderwijs, om tussen 1902 (toen het 'vrije' kunstonderwijs en het kunstnijverheidsonderwijs definitief van elkaar werden gescheiden) en 1945 het meest vernieuwende deel van de academie te worden. Na de Tweede Wereldoorlog kwam er, behalve meer en meer democratisering, steeds meer aandacht voor de ontwikkeling van de individuele creativiteit en leidde de komst van de computer tot een heel andere manier van ontwerpen.

In die 225 jaar waren er wisselende relaties met de gemeentelijke en de landelijke overheid en veranderde de academie diverse malen van naam. In 1851 werd 'Hierdoor tot Hooger' eindelijk van een privégenootschap een stedelijke academie, dat wil zeggen 
de openbare Academie van Beeldende Kunsten en Technische Wetenschappen. Dit was een academie zoals die in het Koninklijk Besluit van 1817 van Willem I van Nederlandse steden werd gevraagd. Ondanks herhaald aandringen van het rijk tussen 1817 en 1851 gevolg te geven aan dit KB, weigerde de gemeente Rotterdam hierop in te gaan en werd steeds verwezen naar het aloude genootschap. Pas in 1851 werd dus aan de eis van de landelijke overheid voldaan. In de jaren twintig van de twintigste eeuw werd de academie tenslotte een rijksinstelling.

Intussen vestigde de academie zich voor het gevoel van de lezer om de haverklap op een nieuwe locatie. Al deze ontwikkelingen worden uitvoerig en zeer adequaat beschreven door de auteur, die haar geschiedenis afrondt in 1998, het jaar van de vorming van de Willem de Kooning Academie. Er zijn liefst twintig bijlagen, met onder meer bestuursleden en docenten, de indeling van het onderwijs op uiteenlopende momenten en in het onderwijs gebruikte didactische literatuur. De literatuurlijst is uitvoerig.

Rotterdamse meesters maakt duidelijk hoe belangrijk de academie voor cultureel Rotterdam was. Omgekeerd is de ontwikkeling van de stad tot een prominente verblijfplaats voor vooruitstrevende architecten en ontwerpers stimulerend geweest voor de academie, waar indertijd Jac Jongert en Piet Zwart docent waren. Het aantal roemruchte docenten en leerlingen is toch al indrukwekkend. Om slechts enkelen van hen in alfabetische volgorde te noemen: Woody van Amen, George Breitner, Sjoerd Buisman, Henk Chabot, Andries Copier, Ad Dekkers, Antoon Derkzen van Angeren, Kees van Dongen, Klaas Gubbels, Willem Hussem, Willem de Kooning, Joep van Lieshout, John Rädecker, Charles Rochussen, Paul Schuitema en Leo Vroegindeweij. Directeur (1965-1969) Pierre Janssen staat hier niet eens bij.

Een groot probleem voor wie schrijft over de Rotterdamse kunstacademie van vóór de Tweede Wereldoorlog is het gebrek aan archivalia. Door het bombardement van 14 mei 1940 werd een groot deel van het archief van de academie vernietigd. Weliswaar biedt J.A. Bakkers De oorsprong der Academie van Beeldende Kunsten en Technische Wetenschappen te Rotterdam aangetoond in de geschiedenis van het teekengenootschap 'Hierdoor tot Hooger' uit 1900 de nodige gegevens, maar het is in de behandeling van de materie gedateerd. De handicap van lacunes in het materiaal heeft Van Giersbergen handig opgelost door materiaal van enkele andere, vergelijkbare academies te gebruiken.

Al met al is dit boek niet alleen interessant voor degene die in de geschiedenis van de Rotterdamse kunst en cultuur geïnteresseerd is, maar levert het ook belangwekkende informatie over onder meer ontwikkelingen in de kunstdidactiek. Hier en daar blijft er nog iets over voor nieuwsgierigen. Zo is er op grond van de intussen opgedane kennis over kunstbeschouwingen bij tekenacademies van de late achttiende en vroege negentiende eeuw meer over deze belangwekkende activiteit te vertellen dan de auteur doet, ook al zijn over kunstbeschouwingen bij 'Hierdoor tot Hooger' niet alle details bekend.

De laatste decennia is de geschiedschrijving over het kunstonderwijs in Nederland in een stroomversnelling geraakt. De conclusie luidt dat Wilma van Giersbergens boek 
over de Rotterdamse kunstacademie ons beeld van ruim tweehonderd jaar 'academisch' kunstonderwijs in Nederland in belangrijke mate verrijkt.

Paul Knolle, Rijksmuseum Twenthe 
Frank de Glas, De regiekamer van de literatuur. Een eeuw Meulenhoff 1895-2000

(Bijdragen tot de geschiedenis van de Nederlandse boekhandel. Nieuwe Reeks 14; Zutphen: Walburg Pers, 2012, 199 pp., ISBN 978905730866 5).

J.M. Meulenhoff behoorde in de twintigste eeuw lange tijd tot de meest gerenommeerde uitgevershuizen in Nederland. Van 1903, het jaar waarin de als boekimporteur gestarte apothekerszoon Johannes Marius Meulenhoff zijn eerste boek publiceerde, tot het einde van het millennium, gaf deze Amsterdamse firma 5.556 afzonderlijke titels uit. Daaronder bevinden zich romans van toonaangevende Nederlandse en Vlaamse schrijvers als Arthur van Schendel, Maurice Gilliams, Jan Wolkers, Anna Blaman, Oek de Jong, Frans Kellendonk, alsook vertalingen van (kandidaat)-Nobelprijswinnaars als Gabriel Garcia Márquez, Mario Vargas Llosa, Philip Roth en Julio Cortázar. Net zo goed produceerde Meulenhoff schoolboeken, kinderboeken en kunstboeken, evenals werk van literaire auteurs die nooit echt zijn doorgebroken. 5.556 Titels, Frank de Glas heeft het allemaal nageteld voor zijn studie De regiekamer van de literatuur. Een eeuw Meulenhoff 1895-2000. De voorbije dertien jaar worden hier wijselijk buiten beschouwing gelaten: het is de periode dat het prestigieuze fonds bijna aan mismanagement ten onder ging, diverse personeelswissels beleefde, kortom, een allesbehalve stabiele periode doormaakte en zo een deel van zijn identiteit onherroepelijk verloren liet gaan.

De regiekamer van de literatuur wil niet echt de geschiedenis van het literaire instituut Meulenhoff vertellen. De Glas' beschrijving van de uitgeverij en zijn portretten van de voornaamste bewindvoerders en medewerkers - J.M. Meulenhoff en diens zoon en opvolger John Meulenhoff, Willem Bloemena, Theo Sontrop, Laurens van Krevelen en anderen - zijn eerder summier en doorgaans gebaseerd op nogal oppervlakkige secundaire literatuur als jubileumuitgaven en interviewboeken. Wat dit betreft heeft De Glas nauwelijks nieuw bronnenonderzoek verricht (en is de meer verhalende bijdrage van Laurens van Krevelen aan de door Gillis Dorleijn en Kees van Rees in 2006 samengestelde bundel De productie van literatuur. Het literaire veld in Nederland 1800-2000 boeiender). Als hij op pagina 21 van Meulenhoffs importactiviteit schrijft dat ze 'is bestempeld als (...) de financiële kurk waar lange tijd het geheel op dreef', dan neemt De Glas dit over van een andere bron. De auteur wil het door hem gereconstrueerde bestand van 5.556 titels in zoveel mogelijk tabellen gieten en op basis daarvan algemene wetmatigheden en uitgeefprocessen op het spoor komen, beschrijven en analyseren. Net als in zijn vroegere, 
voor het Nederlandse en Vlaamse uitgeverijonderzoek baanbrekend gebleken werk - in de eerste plaats zijn doctoraalproefschrift Nieuwe lezers voor het goede boek. De wereldbibliotheek en Ontwikkeling/de Arbeiderspers voor 1940 (1987) - laat hij zich hierbij inspireren door de sociologische geschriften van Pierre Bourdieu, Howard Becker en Richard Peterson. Zo onderzoekt De Glas of de door Meulenhoff uitgegeven tijdschriften (waaronder Criterium, Podium, De Gids en Hollands Maandblad) een impact hebben gehad op de auteursacquisitie. Hij kijkt naar de instroom van debutanten, reconstrueert de oeuvre opbouw van auteurs en brengt de verschuivende verhoudingen in kaart tussen fictie en non-fictie, vertalingen en oorspronkelijk Nederlandstalige titels, en bestsellers en winkeldochters.

Hoewel De Glas helder en prettig sober formuleert, levert zijn cijfermatige aanpak een redelijk droog boek op dat buiten een kring van vorsers en specialisten wellicht weinig lezers zal weten te charmeren. Het bevat jammer genoeg ook nogal wat slordigheden: Abram de Swaan heet op pagina 65 Abraham, Gisèle Sapiro wordt verhaspeld tot Shapiro (187) en het Oegstgeest uit de beroemde roman van Jan Wolkers tot Ooegstgeest (119), noten staan nu eens na dan weer voor de punt (bijvoorbeeld op bladzijde 77). De tabel op pagina 119 van de meest herdrukte titels Nederlandstalige literaire fictie bevat tweemaal Een zwerver verliefd van Arthur van Schendel. Dat neemt allemaal niet weg dat De regiekamer van de literatuur boordevol interessante data staat. Bovendien is de auteur uitstekend op de hoogte van het internationale uitgeverijonderzoek. Hij slaagt er ook in om de inzichten van Peterson, Becker en Bourdieu links en rechts te verfijnen, door ze met zijn tabellen te confronteren. Toch kan wat dit betreft worden opgemerkt dat sommige van De Glas' bevindingen al te veel op evidenties lijken. Dat er een correlatie bestaat tussen literatuurprijzen en herdrukken, dat een tijdschrift als een kweekvijver voor nieuw talent kan functioneren, dat slechts een beperkt aantal goedlopende titels voor het grootste deel van de omzet zorgt, het zijn beweringen die menigeen ook zonder veel tabellen wel zou aandurven. Anderzijds kan het natuurlijk altijd zinvol zijn om intuïties empirisch te staven.

Bij de cijfermatige aanpak van De Glas vallen nog twee andere kanttekeningen te maken. Ten eerste is het jammer dat hij geen volledige fondslijst heeft opgenomen. Zo'n gedetailleerde bibliografie van al wat een uitgeverij heeft gepubliceerd ware nochtans een waardevol instrument voor vervolgonderzoek geweest en had bovendien de lezer beter in staat gesteld om de resultaten van De Glas te controleren. Ten tweede: achter de cijfers gaat vaak meer schuil dan uit De regiekamer van de literatuur blijkt. Ik geef slechts één voorbeeld. Op pagina 97 noemt De Glas de Vlaming Gerard Walschap een van de zeldzame Nederlandstalige fictie-auteurs die via een Meulenhoff-pocketdebuut 'een substantieel oeuvre' bij de uitgeverij zou onderbrengen. De Glas signaleert nog dat Walschaps inbreng zich in een 'heel korte periode (1966-1968)' concentreerde, maar stelt hier verder geen vragen bij. Hij mist zo een relevant verhaal: de 'substantiële' en in een verbazingwekkend korte tijdspanne geleverde bijdrage van Walschap bestond in feite uit herdrukken van de Vlaamse firma Heideland. Meulenhoff distribueerde deze herdrukken 
in Nederland onder de eigen naam louter omdat de Nederlandse boekhandelaren en lezers geen Vlaamse boeken lustten. In een brief aan zijn collega-uitgever Angèle Manteau (d.d. 17 november 1967) schreef de zaakvoerder van Heideland, Lou Nagels, naar aanleiding hiervan over Meulenhoff: 'die Nederlandse uitgever is wel van goede wil (...) [m]aar hij moet misschien rekening houden met een Nederlandse mentaliteit die discriminatoir staat tegenover al wat uit Vlaanderen komt, alle Nederlandse congressen en alle wensdromen over de culturele integratie Noord/Zuid ten spijt'. Gelet op deze in archieven te vinden informatie is het enigszins vertekenend om die herdrukken van Walschap, waar Meulenhoff dus maar weinig mee te maken heeft gehad, gewoon bij het totaal op te tellen. In ieder geval is het belangrijk om het soort machtsrelaties dat hier aan de oppervlakte komt, nauwgezet te bestuderen.

Kortom, cijfers zeggen zelfs als het over literaire bedrijven gaat lang niet alles. Ze kunnen in dit geval bepaalde uitgeefstrategieën helpen te verklaren, ze kunnen inzicht bieden in langetermijnprocessen, maar interpretaties aanreiken doen ze niet uit zichzelf, laat staan dat ze een geschiedenis vertellen. Nochtans is een volwaardig historisch perspectief voor uitgeverijonderzoek onontbeerlijk. De door De Glas zo vaak benutte Pierre Bourdieu zou de eerste zijn om dit te bevestigen. Hij heeft in zijn geschriften voortdurend opgeroepen tot waakzaamheid en scepsis ten aanzien van schijnbaar boven tijd en plaats verheven verklaringsmodellen en voorstellingswijzen. Wie inzicht wil verwerven in het reilen en zeilen van uitgevers hoort volgens de Franse socioloog ook steeds de wording van het literaire veld mee te analyseren. Hoe zijn bepaalde machtsverhoudingen gegroeid, welke discoursen legitimeren bepaalde posities, hoe ontstaan en veranderen literaire smaakpatronen en hegemonieën? Als het om deze en andere vragen gaat, dan moet de geschiedenis van de firma Meulenhoff nog grotendeels geschreven worden. Maar dat De regiekamer van de literatuur bij een dergelijke onderneming behalve voor belangrijke data ook voor tal van aanknopingspunten zal zorgen, lijdt geen twijfel.

Kevin Absillis, Universiteit Antwerpen 
Patricia Faasse, Een beetje opstandigheid. Johanna Westerdijk, de eerste vrouwelijke hoogleraar van Nederland (Amsterdam, Antwerpen: Atlas Contact, 2012, 354 pp., ISBN $9789025439446)$.

De openingszinnen van deze biografie van de eerste vrouwelijke hoogleraar van Nederland lijken veeleer het begin van een spannende roman dan van een doorwrocht wetenschappelijk werk. Eén vraag staat centraal in de proloog, waarmee de auteur meteen de volle aandacht van de lezer vastgrijpt: wat zou Johanna Westerdijk liever anders hebben gedaan tijdens de oorlog, in haar functies van buitengewoon hoogleraar aan de universiteiten van Utrecht en Amsterdam en directrice van het Phytopathologisch Laboratorium Willie Commelin Scholten en het Centraal Bureau voor Schimmelcultures? De overtuiging dat een antwoord onmogelijk is 'zonder verder terug te gaan dan die vijf trieste oorlogsjaren', vormt zo de boeiende aanleiding voor Westerdijks levensverhaal. Door het hele boek heen slaagt de auteur erin deze schrijfstijl vast te houden: vragen opwerpen bij de lezer (en hem zo bij het verhaal betrokken houden) en deze op gezette tijdstippen ook beantwoorden; bijvoorbeeld naar de seksuele geaardheid van het hoofdpersonage, of hoe de uitnodiging in 1905 om directrice te worden van het laboratorium voor plantenziekten uit de lucht kwam vallen - dankzij bemiddeling van Hugo de Vries en ondanks de moeilijke relatie tussen beiden tijdens haar studies - of wat Westerdijk nu eigenlijk heeft bijgedragen aan de wetenschap? Soms waren kruisverwijzingen misschien wel op hun plaats geweest, al was het maar om de lezer gerust te stellen dat zijn vragen verderop wel beantwoord zouden worden.

Een tweede kracht van het boek is het unieke bronnenmateriaal. Met behulp van schoolopstellen, herinneringen van oud-klasgenootjes, haar dagboek en een poëziealbum wordt in het eerste hoofdstuk een vrolijke, onbezonnen kindertijd van een Amsterdams burgermeisje tot leven gewekt. In het tweede en derde hoofdstuk zijn het vooral brieven aan haar boezemvriendin die een beeld verschaffen van haar bezigheden én van haar gevoelens tijdens haar studies in Amsterdam, München en Zürich. En zo gaat het voort. Als intermezzo wordt een lang gedicht van studenten naar aanleiding van haar benoeming tot eerste vrouwelijke (buitengewoon) hoogleraar van Nederland (in Utrecht) ingevoegd. Een brief van één van haar promovendi, die ze zoals vaak gebeurde aan een baan heeft geholpen, biedt een heel open portret van Westerdijk als hoogleraar tijdens haar rondreis in Zuid-Afrika. En de zoektocht naar in welke mate Westerdijk joodse 
vrienden zou hebben geholpen tijdens de oorlog wordt afgerond met onverwachte interviews en persoonlijke documenten met en van onder meer oud-studenten.

Een indringend en soms bijna intiem inzicht in het reilen en zeilen van een vroegtwintigste-eeuwse hoogleraar is dan ook de grote verdienste van het boek. Haar levensmotto 'Werken en feesten vormt schoone geesten', gebeiteld boven de deur van het laboratorium dat vanaf 1920 was gehuisvest in de Villa Java in Baarn, komt op een overtuigende wijze tot leven door de aandacht voor zowel haar eigen wetenschappelijk werk als dat van haar promovendi en collega's, maar ook voor de vormen van persoonlijke ontwikkeling en ontspanning in het laboratorium (en bij Westerdijk soms ontsnapping in de muziek) en voor haar ideeën, opvattingen en twijfels. Eén van haar vaststaande overtuigingen was de strikte scheiding tussen wetenschap en politiek. De wetenschap stond boven alles en was politiek neutraal. 'Antisemitische sentimenten waren haar net zo vreemd als de gangbare mening dat alle Duitsers “fout" waren', wat haar later wel verweten is. Dat het hierbij gaat om een (ongetrouwde) vrouwelijke hoogleraar doet eigenlijk nauwelijks ter zake. Weliswaar was Westerdijk zich ter dege bewust van de beperkingen die haar door haar sekse waren opgelegd, maar voortdurend heeft ze getracht hieraan te ontsnappen. Vrouwen mochten zich in haar ogen niet laten knechten en moesten voor hun zelfstandigheid opkomen.

Het boek biedt op die manier inderdaad 'een verrassende inkijk in het leven van een buitengewone vrouw', zoals aangekondigd op de achterflap, maar de beloofde 'inkijk in de wetenschappelijke wereld van het interbellum' blijft iets beperkter. De context van bijvoorbeeld het indrukwekkend aantal Russische studentes in Zürich omstreeks 1900, de toenemende interesse voor de natuur in het onderwijs, de opkomst van de experimentele wetenschap, de conflictueuze opvolging van De Vries als hoogleraar plantkunde in Amsterdam en het belang van de ontwikkeling van penicilline in de afloop van de Tweede Wereldoorlog wordt wel aangeraakt, maar niet verder uitgewerkt dan noodzakelijk. De auteur realiseert hierbij een mooi, maar wankel evenwicht. Enerzijds getuigt ze van haar grote belezenheid zonder hiermee te koop te willen lopen, maar anderzijds lijkt de biografische focus af en toe ook iets te dominant. De kadering van Westerdijks keuze om verder te studeren in Duitsland in de algemene tijdsgeest en de achtergrond van Afrikaner nationalisme, worden als bekend verondersteld. Enigszins gelijkaardig beperkt de situering in de bestaande historiografie zich tot de vaststelling van het ontbreken van een volwaardige biografie. Er wordt geen aansluiting gezocht met subdisciplines als de universiteits- of wetenschapsgeschiedenis en de lezer blijft ietwat in het ongewisse over hoe deze studie zich verhoudt tot voorafgaand onderzoek, Faasses eigen geschiedenis van het Phytopathologisch Laboratorium Willie Commelin Scholten incluis.

De werking van het laboratorium en de unieke combinatie van én universitair (door Westerdijks positie aan de universiteiten van Utrecht en Amsterdam) én plantenziektekundig (door de aanwezigheid van het laboratorium) én mycologisch (door de aanwezigheid van de geleidelijk wereldvermaarde schimmelcollectie) onderricht komt 
het best tot uiting in het ronduit spannende hoofdstuk over de zoektocht naar de oorzaak van en remedie voor de Nederlandse iepenziekte. Het biedt een prachtig inzicht in hoe wetenschap in zijn werk ging en de conflicten die hiermee gepaard gingen, met de these vanuit Baarn (zijnde de ontdekking van een nieuwe schimmel), de antithese vanuit de (concurrerende) Phytopathologische Dienst in Wageningen (zijnde de nadruk op het belang van uitwendige invloeden) en tenslotte de synthese (zijnde de combinatie van zwam en iepenspintkever), die werd bereikt door een samenwerking tussen beide instellingen. Dit en ander uitgevoerd onderzoek getuigt ook van de toenemende internationale oriëntering van de werkzaamheden in Baarn en de figuur van Westerdijk zelf, onder meer in de richting van Nederlands-Indië, waar Westerdijk enige tijd had doorgebracht, net als de meeste van haar collega-biologen in die periode.

Enkel de keuze van de illustraties lijkt hierbij soms een gemiste kans. Het belang van het onderzoek naar de iepenziekte wordt aangetoond door te wijzen op de manier waarop de iep 'het karakteristieke Nederlandse landschap aan de Zeeuwse dijken en langs de Hollandse groene weiden de charme verleent die het tot ver in het buitenland beroemd heeft gemaakt'. Een illustratie van dit typische landschap had, mijns inziens, de argumentatie nog meer kracht kunnen bijzetten. Het vormt tegelijkertijd ook een voorbeeld van hoezeer het boek zich richt tot een exclusief Nederlands publiek. Maar ook op andere plaatsen had een besproken schilderij, foto of ansichtkaart gerust een zoveelste portret van het hoofdpersonage mogen vervangen. Nochtans doet deze kleine kanttekening niets af aan de indrukwekkende wijze waarop deze studie inzicht verschaft in Westerdijks (ook letterlijk) indrukwekkende verschijning.

Pieter Dhondt, University of Eastern Finland 
Benjamin B. Roberts, Sex and Drugs before Rock ' $n$ ' Roll: Youth Culture and Masculinity during Holland's Golden Age (Amsterdam Studies in the Dutch Golden Age; Amsterdam: Amsterdam University Press, 2012, 318 pp., ISBN 978908964402 2).

The indeterminate 'golden age' in the book's title is quickly specified. Benjamin Roberts wants to write about the males of one specific generation, young in the 1620 s and 1630 s. He further specifies this generation as men born between 1595 and 1615, which means that they were aged from five to twenty-five at the beginning of the period studied and from twenty-five to forty-five at the end. The reason for this focused orientation is explained at the beginning of the prologue. For the twentieth century, historians and demographers identify a number of specific generations that were all distinct in outlook, habits and life experiences. No one would assume that the children of the Great Depression were similar to those who grew up with computer games. Nevertheless, many scholars implicitly assume a single youth culture for the seventeenth century or even the entire early modern period. By contrast, Roberts wishes to show what is specific about the male youth culture of his interest. Surely, its representatives had distinct life experiences. They grew up in a period of economic growth, cultural efflorescence and the resumption of the war against Spain. Roberts' point of departure presents any reviewer with two obvious tasks: to trace 1) to what extent the author deals indeed with the generation of the 1620 s and 1630 s only and 2) to what extent he is able to substantiate the claim that this period witnessed a male youth culture that was in many respects unique.

Before addressing these questions, let me situate this study in its proper historiographical context. In fact, the book under review lies at the crossroads of two venerable historiographical traditions. One is the history of crime and justice, because the book pays ample attention to more or less clandestine behavior in general and violence in particular. The other tradition is that of family history in the broadest sense, including sexuality and stages of life. Of course the theme of masculinity also belongs to gender history, but male cultures are often studied within the context already mentioned, that of violence and honor. As far as phases of life are concerned, the author's remark that adolescence and young adulthood get much less attention from historians than childhood is well taken. 
Moreover, to the extent that youth does get attention, this is often within an agrarian setting (such as in the work of Norbert Schindler, to whom Roberts refers several times), although there are also studies of the culture of urban apprentices and journeymen. Hence, Roberts' focus on youth culture in the cities of the province of Holland forms a useful contribution to the literature. Further, he sensibly distinguishes between the culture of elite youths (from the middle classes and higher, including painters) and that of lower-class youths. The former, however, receive the bulk of his attention. Thus, the records of university courts form a prominent body of evidence, whereas a rich source such as the Amsterdam confession books is left aside. Admittedly, the latter have been studied already by a number of scholars including myself, but precisely for the first half of the seventeenth century this has hardly been the case.

To what extent has Roberts succeeded in his mission? The prologue and chapter one introduce the subject in a general fashion. Thereafter, the focus on the generation of the 1620 s and 1630 s is most rigorously and consistently maintained in chapter two, dealing with appearance and clothing. Roberts convincingly demonstrates that the young men of this generation initiated a complete shift in fashion, many elements of which later spread to all age groups. Young men of the 1620 s discarded the stiff black garments of the older generation, for example, going for a variety of bright colors. Wearing metalliclike jackets, they favored a military look, which Roberts attributes to the increased prestige of the army following the resumption of the war with Spain. For the males of this generation, soldiers served as role models. Although there are over thirty illustrations (many of them repeated in better quality at the end, which I did not discover until finishing my reading), in this chapter we still long for more pictures. I would not be surprised if even native speakers of English have difficulties in imagining what cuffs, jerkins and ruffles look like. The most lasting innovation of the young men of this generation consisted of wearing their hair long - in imitation, despite the relative absence of a court culture in Holland, of two French kings. Not surprisingly, preachers and moralists opposed the new fashion. The more they aged, the more they found themselves tilting against windmills, as even young ministers preferred long hair. This fashion lasted, albeit in the form of wigs, until the French Revolution, which made the youths under study decidedly more successful than my generation of the sixties.

However, in my view the other chapters, fail to a greater or lesser extent either to maintain the focus on the generation of the 1620 s and 1630 s or to convince the reader that this period witnessed a specific youth culture quite different from that of the young men before and after. The resulting lack of focus undermines the raison d'être of the book, since it contains much - on sexuality, violence, alcohol consumption and the like that is already well-known to students of early modern culture. Space does not permit me to make my point in detail for each chapter concerned. Let me concentrate on the chapter about violence. It opens with a claim: 'During the 1620 s and 1630 s there was a visible shift from lethal to non-lethal violence in Dutch cities' (103). I was much interested, since I did not know this. Amsterdam homicide rates, for example, are unavailable for the 
period in question. The rest of the chapter fails to substantiate the author's claim. A discussion of youth companies and charivari ostensibly serves to illustrate the culture that immigrants to Dutch cities left behind. The section on lower-class violence concentrates on the troubles of the $1610 \mathrm{~s}$, which is like illustrating an argument about hippies with nozems. The other pages mainly discuss student violence, with court cases conveniently selected for the decades under study.

Minor reservations concern style of writing and editing. It is perhaps foolish for a non-native speaker to comment on the writing of an American-born author, but the style often looks inelegant to me. My Webster's defines the often-used 'tomfoolery' as 'silly behavior', whereas Roberts uses it as the English equivalent of kattenkwaad [mischief]. The book is also repetitive. Udemans' critique of long hair, extensively discussed in chapter two, is subsequently mentioned several times as if it were a new fact; Jan Jansz Starter's composition of a poem for the wedding of Manuel Colyn and Catharina Cloppenburg is mentioned no less than four times. Finally, there are recurrent errors that could have been prevented by more careful copy-editing.

In sum: Some chapters, in particular the one about fashion, constitute a novel contribution to the study of youth cultures and masculinity, while non-expert readers may find details in other chapters also interesting. However, the book fails in substantiating its primary claim: the existence of a distinct youth culture in the cities of Holland in the $1620 \mathrm{~s}$ and 1630 s.

Pieter Spierenburg, Erasmus Universiteit 
Wim Willems en Hanneke Verbeek, Honderd jaar heimwee. De geschiedenis van Polen in Nederland (Amsterdam: Boom, 2012, 349 pp., ISBN 978946105059 5).

Dit vlot geschreven en mooi geïllustreerde boek is een antwoord op de kliklijn van de partij van Geert Wilders van februari 2012. Het is een boek voor een breed publiek dat de Poolse aanwezigheid in Nederland in al haar heterogeniteit een gezicht wil geven. De auteurs willen met dit boek de lessen die historici trekken uit het Nederlandse migratieverleden meer ruchtbaarheid geven. Zij wijzen op een vast patroon in de Nederlandse houding ten opzichte van nieuwkomers. De Nederlandse immigratiesamenleving heeft volgens de auteurs steeds potentiële immigranten willen ontmoedigen en heeft, als ze zich dan toch vestigen in Nederland, hun aanwezigheid steeds ontkend. Nederland heeft zichzelf nooit beschouwd als een immigratieland en nooit een daarop afgestemd beleid gevoerd. Ook in de eenentwintigste eeuw bij de immigratie van Polen is dat het geval. Hun komst wordt beschouwd als een slechts tijdelijke noodsituatie. Het geloof in de tijdelijke aanwezigheid van immigranten wordt herhaald. Zelfs sociaal wetenschappers onderschrijven die stelling, waarop ze vooral wijzen op het verdampen van de grenzen binnen de Europese Unie en de veel hogere mobiliteit binnen het Europa van de eenentwintigte eeuw die vestiging minder noodzakelijk maakt om te kunnen gebruik maken van de opportuniteiten in Nederland. Dat deze opportuniteiten vooral seizoenarbeid betreft, versterkt nog hun betoog.

De stelling dat er bij de hedendaagse Polen sprake is van een louter tijdelijke arbeidsmigratie staat volgens de auteurs van dit boek op gespannen voet met de inzichten uit historische studies naar migratie. Immers, tweedederde van de nieuwkomers, ondanks hun veelal zelf gekoesterde terugkeerproject en in ieder geval door de Nederlandse verwachte terugkeer, zouden zich uiteindelijk gevestigd hebben in Nederland. De auteurs wijzen op de nieuwe Europese arbeidsmarkt waarvan de Polen een deel vormen en ook op de structurele arbeidsnoden in Nederland, die door de vergrijzing nog zullen toenemen. Dit zal Nederland een blijvende aantrekkingskracht doen uitoefenen op de Polen. De auteurs willen wat zij 'de mythe van de tijdelijkheid' noemen, ontkrachten. Het is een synthese van reeds bestaande onderzoeksinzichten samengebracht in een boek gestructureerd rond de Poolse migrant in verschillende gedaanten. Het persoonlijk karakter van het boek wordt uitvoerig geïlustreerd met 
foto's. Het hoofdstuk van Poolse kunstenaars in Nederland bestaat zelfs exclusief uit beeld.

In de Nederlandse volkstellingen werden gedurende de twintigste eeuw steeds een vijfduizendtal Polen geregistreerd. De aantrekkingskracht van Nederland op Polen was uiterst gering, zeker als we dat vergelijken met het aantal Polen in Frankrijk en België of zelfs de Verenigde Staten. Het aantal Polen steeg explosief in de laatste decennia om in 2012 tot honderdduizend op te lopen. In antwoord op de arbeidsnoden in Nederland en het opnemen van Polen in de Europese politieke ruimte zijn massaal Polen naar Nederland afgezakt. Vooral arbeidsmigranten, maar ook studiemigranten en partnermigranten hebben zich een plaats veroverd in Nederland.

De terugblik in de tijd gebeurt aan de hand van persoonlijke levensverhalen van een aantal kleurrijke figuren. De helft van het boek bestrijkt de periode tot 1980 met onder meer het levensverhaal van een Poolse mijnwerker, een Poolse jood en een Poolse rechter aan het Internationale Hof in Den Haag. Het tweede deel van het boek gaat over de periode vanaf 1980, met een aantal Poolse Nederlanders die toen bij de linkerzijde aandacht vroegen voor de oppositie in communistisch Polen. In dit hoofdstuk is de thematiek van de Poolse migratie afwezig. Het gaat vooral over de Nederlandse discussie over Polen, waarbij deze discussie in feite niet ging over Polen zelf, maar Polen eerder fungeerde als een spiegel voor Nederland zelf. Het boek sluit af met de hedendaagse migratiesituatie met een aantal portretten van huwelijksmigranten en kunstenaars, en dan vooral de Poolse arbeidsmigranten in de vleesfabrieken, bouw en bloemenkassen. Zowel deze arbeidsmigranten zelf als de veelal ongenuanceerde berichtgeving over hen wordt uitvoerig belicht.

Honderd jaar heimwee betreft geen wetenschappelijke studie met nieuwe inzichten, maar een vlot leesbaar boek over mensen uit de Poolse migratie voor een breed publiek. Ondanks de lange tijdhorizon die gehanteerd wordt, krijgt het veranderende vreemdelingenbeleid of de nieuwe mobiliteitssituatie geen aandacht. Het boek is ook heel sterk op Nederland gericht. Wat het belang is van Nederland binnen de Poolse migratiegeschiedenis wordt niet geproblematiseerd. Wat de specifieke aantrekkingskracht van Nederland op Polen uitmaakte door de geschiedenis heen wordt niet bevraagd. Zo moest bijvoorbeeld de Pools-joodse emigratie na het quasi sluiten van de Amerikaanse toegangspoort begin jaren twintig van richting wijzigen en werd niet Nederland, maar wel België en Frankrijk de uitverkoren bestemming. Dergelijke vragen komen jammer genoeg niet aan bod. Toch hebben de auteurs met een beperkte agenda een mooi boek geschreven dat als tegengif kan dienen tegen de hysterische reacties in Nederland op de recente Poolse migratie.

Frank Caestecker, Universiteit Gent 
Pim Griffioen en Ron Zeller, Jodenvervolging in Nederland, Frankrijk en België, 1940-1945.

Overeenkomsten, verschillen, oorzaken (Bewerking van dissertatie Universiteit van Amsterdam 2008; Amsterdam: Boom, 2011, 1045 pp., ISBN 978908506811 2); Insa Meinen, De Shoah in België (Antwerpen: De Bezige Bij Antwerpen, 2011, 331 pp., ISBN 978 908542283 9); Ad van Liempt en Jan H. Kompagnie (eds.), Jodenjacht. De onthutsende rol van de Nederlandse politie in de Tweede Wereldoorlog (Amsterdam: Balans, 2011, 352 pp., ISBN 978946003368 1).

Het is verbazingwekkend dat hoe langer de Shoah geleden is, hoe meer onderzoek erover verschijnt. Sinds de val van het communisme is in het onderzoek op het gebied van de Tätergeschichte ('daders-geschiedenis') de nadruk komen liggen op het gebeuren in OostEuropese landen, met als duidelijk resultaat de recente bestseller van Timothy Snyder: Bloodlands: Europe Between Hitler and Stalin (2010). Hij claimt in feite dat de Shoah (in de zeer beperkte betekenis van 'de moord op de joden') deel uitmaakt van een veel groter Oost-Europees historisch gebeuren: de massale moord (door executies, vergassing en verhongering) op meer dan 14 miljoen 'non-combatants' in de landen tussen centraal Polen en de Zwarte Zee in de jaren dertig en veertig van de vorige eeuw. Deze kijk op de Shoah marginaliseert de niet-Oost-Europese hoofdstukken daarvan, inclusief dat van West-Europa. Het onderzoek over West-Europa, dat wat Nederland en Frankrijk betreft al een tientallen jaren oude traditie heeft, zou daarom veel meer bekendheid buiten deze landen moeten krijgen om beter geïntegreerd te kunnen worden in het algemene beeld. De hier gerecenseerde studies vallen alle drie onder de noemer 'de Shoah in West-Europa', maar zijn zeer verschillend van aard. Ze zijn niet vergelijkbaar als zodanig, maar hebben wel alle te maken met de hoofdvraag van de Tätergeschichte: hoe kon het doel van het Nazi anti-Joodse project - de 'Entfernung der Juden überhaupt' (Hitler, 1919) - in zo korte tijd en met zo groot succes uitgevoerd worden? Daarnaast staat in alle boeken de rol van de politie in de Jodenvervolging centraal. Als zodanig zijn deze studies van belang om de genoemde verstoorde balans weer enigszins recht te kunnen zetten.

Griffioen en Zellers studie is de bewerkte boekversie van hun proefschrift (Universiteit van Amsterdam 2008). Hun vraagstelling is dezelfde als die de Nederlandse geschiedschrijving over de Shoah al tientallen jaren bezighoudt: waarom ligt het 
percentage slachtoffers van de Nederlands-Joodse gemeenschap - ongeveer $75 \%$ (iets meer dan 104.000 mensen) - zoveel hoger dan in Frankrijk (ongeveer 80.000; 25\%) en België (25.000; iets meer dan 40\%)? Griffioen en Zellers aanpak is echter essentieel anders dan die van hun voorgangers. Zij hebben gekozen voor een zeer uitgebreide en minutieuze internationale drielandenvergelijking. Methodologisch volgen ze geschiedfilosoof Chris Lorenz' 'vergelijkende oorzakelijke verklaringswijze', volgens welke historische ontwikkelingen wel vergelijkend doch kwalitatief worden beoordeeld. Dit in tegenstelling tot de tot nog toe enige vergelijkende studie van nationale verschillen tijdens de Shoah, van de Amerikaanse sociologe Helen Fein (Accounting for Genocide, 1979), waarin zij onsuccesvol poogde historische variabelen te kwantificeren.

Griffioen en Zellers vraagstelling is drieledig. Ze vragen zich af in welke mate overeenkomsten en verschillen in bestuur, onderlinge verhoudingen en reacties bij de bezetter, omgeving en joodse bevolkingsgroepen in Frankrijk, België en Nederland van belang waren om de grote verschillen in aantallen Joodse slachtoffers te verklaren. Daarnaast zoeken ze de factoren die daarbij van primaire dan wel secundaire betekenis waren en wat de oorzaken daarvan waren. Tot slot onderzoeken ze welke wisselwerking er bestond tussen de drie groepen in de afzonderlijke landen. Om deze vragen te kunnen beantwoorden hebben de auteurs zo goed als alle relevante literatuur gelezen - in het Nederlands, Fans, Duits, Engels en Hebreeuws - en waar nodig ook zelf aanvullend archiefonderzoek gedaan.

In deze recensie kunnen niet alle conclusies van Griffioen en Zeller vermeld worden, maar hun meest fundamentele conclusies betreffende Nederland zijn: de belangrijkste oorzaak voor het hoogste percentage en hoogste aantal slachtoffers van de Jodenvervolging in Nederland was 'de vrijwel onbeperkte zeggenschap van de Duitse politie over de organisatie en uitvoering van de deportaties'. Griffioen en Zeller benadrukken dat de centrale Duitse autoriteit die verantwoordelijk was voor de uitvoering van de Endlösung - de SS en de politie - al vroeg de overhand had in het Duitse bezettingsapparaat, dat wil zeggen tegenover minder ideologische en minder gecommitteerde Duitse instanties. Zodoende kon zij zich ook van de verregaande medewerking van de Nederlandse politie verzekeren zonder daarvoor teveel pressie te moeten uitoefenen op de hogere Nederlandse instanties. Een tweede belangrijke oorzaak was de late opkomst van het verzet en de onderduikmogelijkheden in Nederland, een gevolg van de gunstigere economische situatie in Nederland tot later in de oorlog 'en de in België en Frankrijk eerdere en grotere schok van de invoering van de verplichte tewerkstelling voor niet-Joden in Duitsland'. Wat de kant van de Joodse bevolking betreft, benadrukken Griffioen en Zeller de veel extremere manier waarop de Joodse Raad door de Duitse deportatieautoriteiten onder druk gezet en gemanipuleerd werd, en de manier waarop de Joodse gemeenschap reageerde als gevolg van hun vooroorlogse achtergrond als geïntegreerde burgers met een traditie van 150 jaar emancipatie.

In zekere zin zijn deze conclusies van Griffioen en Zeller niet nieuw; wat het verzet en de Joodse Raad betreft, zijn deze oorzaken al eerder gesuggereerd (onder andere 
door deze recensent). Ook de rol van de Nederlandse politie is al gedeeltelijk eerder behandeld (en zie de bespreking van Van Liempts bundel verderop). Doch deze conclusies worden nu veel sterker in het grotere beeld verankerd dan voorheen. Ook maken zij duidelijk dat het uiteindelijk vooral aan de assertiviteit van en de interne machtsverhoudingen in de Duitse bestuursapparaten en hun plaatselijke medewerkers lag, hoe effectief de, in Raul Hilberg's terminologie, 'machinery of destruction' uiteindelijk zou zijn.

Er zij hierbij opgemerkt dat Griffioen en Zellers methodologie uniek is in de (Shoah-) geschiedschrijving. Hun methode kan echter slechts in weinig gevallen gebruikt worden voor andere landen en onderwerpen. Het gaat hier om drie West-Europese democratieën met zeer veel overeenkomsten. In 2013 heeft deze recensent echter aangetoond dat een verklaring die zich tot West-Europa beperkt zijn grenzen heeft (zie Cüppers, Matthäus en Angrick (eds.), Nationalsozialistische Verbrechen. Taten und Bewältigungsversuche). Toch zal deze studie ongetwijfeld tot de meest fundamentele studies over de Shoah in het algemeen en over West-Europa in het bijzonder gaan behoren.

Insa Meinens boek is de Nederlandse versie van haar reeds in het Duits verschenen studie. De Duitse onderzoekster is een van de weinige niet-Belgen die zich over de Shoah in dit land hebben gebogen. De enige vorige pogingen tot een omvattende studie van de Shoah in België zijn de baanbrekende driedelige studie van Maxime Steinberg uit de jaren tachtig en zijn twee latere interpretaties (ter vergelijking: over Nederland verscheen al in 1947 het boek van Wielek, daarna de boeken van Herzberg, Presser, De Jong, MichmanBeem, Michman, Moore en enkele kortere overzichten). Meinen schreef al eerder verschillende belangrijke studies, die nu grotendeels in dit boek geïntegreerd zijn. De titel De Shoah in België wekt echter te hoge verwachtingen. De auteur schrijft zelf in haar inleiding dat 'volledigheid [... ] niet het streefdoel van deze monografie' was. Verschillende kwesties, zoals de beroving van de Joden en het interne leven van de Joodse gemeenschap in deze jaren, zijn al in andere studies behandeld of tot op heden niet grondig onderzocht, ook niet door Meinen. Ook valt te betreuren dat deze Nederlandstalige versie een nauwkeurige vertaling van de Duitse blijft, zonder de nodige aanpassing aan het Nederlandstalige lezerspubliek. Toch is deze studie een belangrijke bijdrage tot het onderzoek over voornamelijk de jaren 1942-1944. Ze is gebaseerd op veel bronnen die door vorige onderzoekers niet bekeken zijn en brengt frisse inzichten.

De principiële vraag die behandeld wordt en waarop Meinen originele antwoorden geeft, is: hoe werd de Endlösung uitgevoerd en welke factoren hadden invloed op de uiteindelijke uitkomst? Haar conclusie is anders dan wat in de laatste jaren in België gesuggereerd is en waarin de rol van de Belgische instanties benadrukt wordt. Ten eerste was de rol van de Militärverwaltung doorslaggevend - deze beschikte 'over de wil en bekwaamheid om de maatregelen die Berlijn vastlegde af te stemmen op de reële politieke behoeften', en slaagde daar zodanig in dat de arrestaties en deportaties tamelijk rustig uitgevoerd konden worden (hierin verschilt Meinen in zekere zin van Griffioen en Zeller). Volgens Meinens onderzoek was de bijdrage van de Belgische politie aan de 
arrestaties van Joden beperkt. Een belangrijke conclusie is dat 'in tegenstelling tot in Frankrijk en Nederland [... ] de meerderheid van de Joden die uit België werden gedeporteerd niet gearresteerd [werd] tijdens de grote arrestatieacties, maar individueel of in kleine groepen, waarbij medewerking van de Belgische politie eerder de uitzondering dan de regel was' (243). Het succes lag aan de samenwerking van verscheidene Duitse instanties, ook degenen die officieel niet aan de Endlösung hoefden deel te nemen, en de hulp van lokale collaborateurs en informanten - zo'n 56\% van de gearresteerden in België werd op deze manier gepakt. Een andere belangrijke conclusie is dat de initiatieven tot zelfbehoud van Joodse kant, in menig geval geholpen door nietJoodse verzetsorganisaties, wel degelijk een belangrijke bijdrage hebben geleverd aan het overlevingspercentage. Meinen zet dit met name uiteen in haar minutieuze analyse van de achtergrond en persoonlijke samenstelling van het 21ste konvooi naar Auschwitz, dat eind juli 1943 vertrok en een van de grootste transporten vanuit België was.

Meinens laatste hoofdstuk, dat de opsporingsactiviteiten van ondergedoken Joden beschrijft, heet 'Mensenjacht'. Jodenjacht is de titel van de bundel over de rol van de Nederlandse politie in de arrestatie en opsporing van ondergedoken Joden in Nederland na het begin van de deportaties in de zomer van 1942. Deze studie werd geïnitieerd door Ad van Liempt (bekend van zijn vorige boek over dit onderwerp Kopgeld, 2001), en Jan H. Kompagnie (archivaris en onderzoeker bij het Nationaal Archief). Zes onderzoekers - Marie-Cécile van Hintum, Margot van Kooten, Anne-Marie Mreijen, Elias van de Plicht, Liesbeth Sparks en Caroline Willers - bestudeerden gedurende zes maanden ongeveer 280 naoorlogse strafrechtelijke dossiers van politiebeambten, waarin meer dan 9000 namen van door hen opgepakte Joden stonden vermeld. Aanvankelijk was de bedoeling informatie te verzamelen ter kennis van nabestaanden en het Digitaal Monument Joodse Gemeenschap, maar wegens de overvloedigheid van het materiaal werd besloten dit ook te bestuderen. In zeven hoofdstukken worden verschillende aspecten van de Jodenjacht beschreven (organisatie, verraad, geweld, geld, drijfveren en de naoorlogse berechtiging) en krijgen we een inzicht in het werk van de speciale politiële afdelingen die in verschillende steden werden opgericht voor dit doeleinde. Daar de documentaire basis van de studie voornamelijk uit persoonlijke gevallen bestaat, krijgt de lezer naast het algemene beeld kleurrijke en gedetailleerde close-up beschrijvingen van de betrokkenen en hoe zij te werk gingen; een vaak onthutsend beeld.

De studies van Griffioen en Zeller en Meinen zijn hoofdzakelijk voor specialisten geschreven, maar Jodenjacht van Van Liempt en Kompagnie is zeer toegankelijk voor een algemeen publiek. Eigenlijk belicht dit boek van binnenuit wat Griffioen en Zeller in hun grote analyse vaststellen: 'In feite werd de Nederlandse politie steeds meer een werktuig van de bezetter' (16). Van Liempt en Kompagnie relativeren hun stelling door eraan toe te voegen dat het 'toch [... ] niet rechtvaardig [is] elke individuele politiebeambte medeplichtigheid aan de Jodenvervolging in de schoenen te schuiven' (29). Tegelijk laten ze zien dat juist de speciaal opgerichte eenheden van 'Jodenjagers' het mogelijk maakten voor de doorsnee niet-Jodenhaters in de politie de andere richting uit te kijken, waardoor 
de politie als geheel als werktuig kon dienen voor de Duitse bezetter. Wat dat betreft kan deze studie goed gebruikt worden bij maatschappelijke vorming.

Dan Michman, Bar-Ilan Universiteit en Yad Vashem, Israël 
Heidi de Mare, Huiselijke taferelen. De veranderende rol van het beeld in de Gouden Eeuw (Nijmegen: Vantilt, 2012, 607 pp., ISBN 978946004066 5).

In Huiselijke taferelen. De veranderende rol van het beeld in de Gouden Eeuw [Domestic Scenes: The Changing Role of the Image in the Dutch Golden Age] Heidi de Mare argues that in the early modern period the image served as an instrument by which knowledge of the natural world could be produced. Following Michel Foucault for whom history unfolds not gradually but through a series of epistemological ruptures, De Mare observes how Holland of the seventeenth-century gave rise to a new episteme, or a constellation of knowledge, in which the dominant, religious image-concept had been replaced by what she calls the 'early modern image-concept'. Influenced by Svetlana Alpers, Pamela Smith and Claudia Swan, among others, De Mare wishes to demonstrate that seeing is a form of knowing, and she does this by offering an exploration into Pieter de Hooch's kamergezichten or interior scenes.

In many ways, this book is one continuing celebration of the immense potential of the image as a product as much as a producer of knowledge. True to the interdisciplinarity that De Mare advocates, De Hooch's work is placed in the context of Simon Stevin's architectural designs of houses, Jacob Cats' literary instructions for running a perfect household, and Samuel van Hoogstraten's treatise that encourages young artists to first study the world before starting to paint it. The three chapters on Cats, Stevin and the interior scene that form the core of this lengthy study are preceded by an elaborate discussion of the position of Aristotelian thought in early modern Europe through which, De Mare insists, the changing concept of the image should be understood.

For De Mare, De Hooch's domestic scenes are neither realistic snapshots of the past, nor moralistic puzzles to be deciphered, but rather exercises in translating visual properties of the contents of a room into paint. His oil paintings are brought up as examples of sites where the minutiae of domestic visuality were studied: the patchwork of doors, windows and walls within one composition, the reflection and refraction of light and shadow falling onto them, the appearance of objects against it such as chairs and benches, pots and pans, books and candles, and, ultimately, the bodies placed within them. De Mare asserts that De Hooch, and artists like him, studied closely the ways hands hold pens, needles, or apple skins, bodies bend, sit, or turn, or how light plays of on a fold in a silk dress: it is as if we see De Hooch's hungry gaze zooming in on these things all the 
while recording them in paint. By comparing Van Hoogstraten's art theory with De Hooch's paintings, De Mare points out that these artists, by closely following instructions, in fact put the theory of seeing as knowing into practice.

However, despite its compelling argument on De Hooch, the book bites off more that it can chew. Instead of further developing the main argument about De Hooch and the changing image-concept, this study offers long reviews of the current literature on various topics that read as state-of-the-field reports. These literary overviews are filled with sharp criticisms, finger-wagging and sweeping statements, resulting from a deep suspicion of art historical and theoretical discourse. De Mare is quick with her critique yet slow in offering alternatives. As a result, the book is at once too much and not enough. Too much are lengthy expositions on nineteenth century myths and clichés around Dutch domesticity and artistic genius, on Plato's hostility towards images, on Jan Steen's topsyturvy households et cetera. What the book leaves out are key concepts, essential ideas and crucial scholarly works that would have enabled De Mare to make her criticism productive. For instance, it is inconceivable that she as a self-declared image-scientist (beeldwetenschapper) refrains from mentioning the German field of Bildwissenschaft that brings together early modern art, science, and natural philosophy in a very exciting and very fruitful way. Another mystery is why interpretation is termed a 'by-product of human history' (573), while the alternatives De Mare presents in the form of 'slow looking' and 'close-reading' are both very much interpretive practices coming out of semiotics. Methodological inconsistencies such as these are numerous, and accumulate at the end of the book, when historical formalism is proposed as a way out of the impasse created by art historical over-interpretation and the dominant, nineteenth century-based art historical paradigm. However, if there is one approach that might propel us straight back into nineteenth century ideology, it is formalism.

But what concerns me most is the status of the unusual format of the lavish reproductions that have been inserted as separate folders at the end of each chapter. Most pages display twenty-odd thumbnail figures, sometimes only of details, headed by a general theme, and lacking proper captions. Surprisingly, various covers of books mentioned in the text are illustrated as well, while their presence remains unjustified (the covers have not been discussed in the text). Evidently, this lay-out is inspired by Google image search and my guess is that De Mare wants to let her selection of examples speak for itself as a visual argument as such. But it does not work. In a scholarly work that is about changing image conceptions, and that fulminates against contemporary scholarship that presumably refuses to look at art properly, it is remarkable, to say the least, that the size of the reproductions preclude any form of slow looking or close reading that the reader is encouraged to carry out. (The reader's engagement with materials is generally frustrated, as there are, for instance, no proper footnotes either, even when quotations have been given.) Moreover, one would have hoped that De Mare had acknowledged that the repetition of motives and patterns that we spot in De Hooch's work are brought about by the very conditions of their reproduction as series of 
thumbnails in her book. However, like most of us image-lovers, De Mare probably has been carried away by the overwhelming riches of visuals available online, feeding upon them from behind the computer screen, only to forget that the patterns we discover in thumbnail reproductions today are likely to stand at the foundations of the art historical myths of tomorrow.

Hanneke Grootenboer, University of Oxford 
Rob Hartmans, Vijandige broeders? De Nederlandse sociaal-democratie en het nationaalsocialisme, 1922-1940 (Amsterdam: Ambo, 2012, 339 pp., ISBN 978902632110 8).

Bestonden er fundamentele overeenkomsten tussen de sociaal-democratie enerzijds en het nationaal-socialisme anderzijds? Was Adolf Hitler wellicht een socialist? Waren de Duitse sociaal-democraten medeverantwoordelijk voor de machtsovername van Hitler in 1933? Als we deze vragen met 'ja' beantwoorden, wat betekent dit oordeel over Duitse socialisten dan voor leden en aanhangers van de Sociaal-Democratische Arbeiderspartij (SDAP) in Nederland? Het zijn deze, door PVV-er Martin Bosma (De schijn-élite van de valse munters. Drees, extreem rechts, de sixties, nuttige idioten (2010)) en de socioloog J.A.A. van Doorn (Duits Socialisme. Het falen van de sociaal-democratie en de triomf van het nationaal-socialisme (2007)) geformuleerde vragen (en hun antwoorden) waarvan Rob Hartmans in zijn Vijandige broeders? afstand neemt. Terwijl hij met de eerstgenoemde op niet misverstane wijze korte metten maakt, beargumenteert Hartmans dat de situatie waarin de SPD zich aan het begin van de jaren dertig bevond, onvergelijkbaar was met die van haar Nederlandse zusterpartij. Haar pogingen de NSDAP een halt toe te roepen ten spijt, was de SPD vooral machteloos omdat de meeste Duitsers (en niet alleen zij die op Hitler c.s. stemden) kozen voor een ondemocratische 'oplossing' van hun problemen. Hartmans gaat echter een stap verder: hij laat op overtuigende wijze zien hoe en waarom de SDAP, juist vanwege de dreiging uitgaand van fascisme, veranderde van een socialistische arbeiderspartij in een hervormingsgezinde partij die vele groepen in de samenleving wilde aanspreken. De partij omarmde de parlementaire democratie en accepteerde zelfs de monarchie en het leger; twee instituties die zij voorheen fel had bestreden.

Het grootste deel van Hartmans' boek beschrijft dit proces van heroriëntatie dat zich in een kort tijdsbestek (1933-1937) voltrok. De machtsovername van Hitler stelde het geloof in de wetmatigheden volgens welke de crisis van het kapitalisme zou leiden tot een socialistische overwinning ter discussie. Het optimisme bleek een illusie, omdat de electorale groei van de SDAP stagneerde en geen partij bereid was een coalitie met haar aan te gaan. Toen bovendien de NSB haar successen boekte, argumenteerden sommige sociaal-democraten dat het roer om moest. De herbezinning die onder andere leidde tot het beginselprogramma van 1937 is al vaker beschreven door onder anderen P.J. Knegtmans (Socialisme en democratie. De SDAP tussen klasse en natie, 1929-1939 (1989)) en 
Bart Tromp (Het sociaal-democratisch programma. De beginselprogramma's van SDB, SDAP en PvdA 1878-1977 (2002)). Hartmans' analyse onderscheidt zich hiervan op twee punten. Voor hem was de verandering van de SDAP vooral een antwoord op een politieke dreiging. Bovendien benadrukt hij de voortrekkersrol die de religieus-socialist Willem Banning zou hebben gespeeld. Voortbordurend op een analyse van het fascisme, keerde Banning zich tegen de exclusieve oriëntatie door de sociaal-democratie op de arbeidersklasse. De samenleving was gecompliceerder dan het idee van een tweedeling in kapitaal en proletariaat deed geloven. Banning betoogde dat de sociaal-democratie ten onrechte geen belangstelling voor groepen (zoals de jeugd) had, hoewel zij, gelet op hun geest van verzet, tot de aanhang van de SDAP hadden kunnen behoren. Dit bood Hitler en anderen de kans, de non-rationele angsten en behoeften van de 'labiele massa' aan te spreken; zij boden hen niet alleen een gemeenschapsgevoel, maar tevens een leider, die de 'sociale en nationale wrokgevoelens' aansprak (138-140). Nadat de opkomst van de NSB stagneerde, verschoof de aandacht naar het buitenland: de Duitse nazi-dictatuur en toenemende oorlogsdreiging overtuigden de SDAP van de noodzaak, de democratie en de nationale vrijheid te verdedigen. Haar socialisme werd een nationaal socialisme, geschreven, zoals Hartmans benadrukt, 'zonder koppeltekens of ronde haakjes' (235).

Hartmans biedt een goed geschreven uiteenzetting van de dilemma's waarvoor de SDAP zich in de jaren dertig geplaatst zag. Met hun beginselprogramma van 1937 namen de sociaal-democraten definitief afscheid van hun marxistische zekerheden. Als zodanig formuleerden zij een uitgangspunt, waarop de latere PvdA na de oorlog kon voortborduren. De nadruk waarmee de SDAP (net als de SPD) de parlementaire democratie verdedigde, maakt duidelijk dat Bosma's suggestie dat socialisme en fascisme loten van dezelfde stam waren, klinkklare onzin is - iets waaraan Hartmans en passant fijntjes herinnert. Tevens levert Hartmans overtuigende argumenten voor een herwaardering van de rol van Banning, aan wie andere historici vaak een eerder marginale rol toekennen. Als zodanig is zijn Vijandige broeders? bijzonder aanbevelingswaardig voor iedereen met belangstelling voor de geschiedenis van de sociaal-democratie of de jaren dertig.

Wie het werk van Hartmans gelezen heeft, herkent veel, waaronder zijn nadruk op de heldenrol van Banning. Dit is begrijpelijk, aangezien Vijandige broeders? gebaseerd is op zijn doctoraalscriptie uit 1987 en op zijn artikelen eerder gepubliceerd in onder andere Socialisme en Democratie. Dit boek maakt dit onderzoek toegankelijk voor een groter publiek. Wellicht beïnvloed door Banning, die in vooral politiek-ideologische en sociaalpsychologische categorieën dacht, herkent men ook de neiging economische factoren een minder belangrijke invloed op de ontwikkeling van de SDAP toe te dichten. Dit uit zich bijvoorbeeld in de terloopse manier waarop Hartmans het Plan van de Arbeid uit 1936 bespreekt, hoewel dat toch cruciaal was voor de verandering van de SDAP. Met dit in Europees opzicht gematigd plan richtte de partij zich op een planmatige hervorming van het kapitalisme. Hartmans overtuigt als hij wijst op de invloed van de opkomst van het fascisme. Minder overtuigend is zijn argument dat de oorlogsdreiging mede tot 
verandering heeft geleid, omdat de vernieuwing grotendeels was voltooid (in 1937) voordat de dreiging van een grootschalige oorlog als reëel werd ervaren.

Hartmans en zijn tegenstanders schrijven over al dan niet bestaande fundamentele overeenkomsten tussen sociaal-democratie en fascisme. Terwijl voor de laatstgenoemden 'links' en 'extreem rechts' loten van dezelfde stam waren, benadrukt Hartmans de onderlinge verschillen en laat hij zien hoe het socialisme juist veranderde om het fascisme te bestrijden. Impliciet beschouwen ze allen de jaren dertig als een opmaat naar de door oorlog en genocide gekenmerkte jaren 1939-1945, en bespreken ze reacties van partijen op welbekende sociale en politieke gebeurtenissen. Ze hebben echter minder oog voor wat recent internationaal onderzoek een cruciaal aspect van de politieke cultuur in de jaren dertig heeft genoemd: de noodzaak voor partijen, die, anders dan het liberalisme, sociale groepen of de gemeenschap een centrale rol toekenden, om 'het volk' te herdefiniëren. De Engelse historica Jessica Wardhaugh bijvoorbeeld toont op fascinerende wijze hoe partijen in Frankrijk, van uiterst links tot extreem rechts, le peuple, in wiens naam zij politiek actief wilden zijn, voor zich trachtten te winnen. (In Pursuit of the People. Political Culture in France, 1934-39 (2008)). Ze bespreekt verschillen en overeenkomsten en laat zien hoe partijen op elkaar reageerden en zelfs van elkaar 'leenden'. Ze schetst aldus een beeld van complexe verbanden tussen concurrerende partijen. Dit leentjebuur spelen bestond ook in Nederland, hoewel het partijenlandschap vanwege de verzuiling vooralsnog minder instabiel bleek. Zo 'leende' de NSB de kettingactie als vorm van demonstratie van SDAP, een reden voor de SDAP om van het gebruik hiervan later af te zien. Ook hier streden partijen met elkaar over het symbolische bezit van 'de natie'. Zo moest de SDAP beslissen wie, behalve de traditionele achterban van fabrieksarbeiders, tot haar gemeenschap behoorde en hoe en waarvoor ze die nieuwe groepen wilde mobiliseren. In zijn nabeschouwing over neoliberale praktijken en ideeën sinds de jaren 1990 stipt Hartmans dit probleem voor de huidige PvdA aan; zijn boek zou nog interessanter geweest zijn als hij dit ook zou hebben gedaan voor de SDAP in de jaren dertig.

Bernard Rulof, Universiteit Maastricht 
Hans Renders en Binne de Haan (eds.), Theoretical Discussions of Biography: Approaches

from History, Microhistory, and Life Writing (Lewiston, NY [etc.]: The Edwin Mellen Press, 2013, 434 pp., ISBN 978077344092 0).

In 2009 vond de oprichting van de Europese afdeling van de International Auto/Biography Association plaats en een jaar later zag de Biographers International Organization het licht. Niet alleen de groei van de beroepsverenigingen laat iets zien van de toenemende academische belangstelling voor levensbeschrijvingen, ook het aantal als dissertatie verdedigde biografieën neemt toe. In de bijbehorende behoefte aan theoretische verdieping voorziet in Nederland onder meer het sinds 2004 aan de Groningse universiteit gevestigde Biografie Instituut. Deze instelling organiseerde interessante conferenties over bijvoorbeeld het privé leven in de politieke biografie. Onlangs verscheen onder redactie van de directeur van dit instituut, Hans Renders, en zijn promovendus Binne de Haan, de bundel Theoretical Discussions of Biography. Zij tekenden eveneens voor de helft van de twintig bijdragen.

Het accent van de publicatie ligt op theoretische discussies over de biografie, Life Writing en microhistory. De redacteuren willen duidelijk maken waar deze begrippen voor staan en beogen een handboek te schrijven. Maar ze willen ook de aanval inzetten op Life Writing en microgeschiedenis naar voren schuiven als een nieuwe inspiratiebron voor de beoefening van de biografie. Naast bijdragen over de hoofdthematiek bevat de bundel een appendix met zes kleinere losse bijdragen zonder veel samenhang, waaronder een over 'sex in biography' van Ernst Boyd (uit 1932). De overlap tussen diverse stukken doet soms afbreuk aan de leesbaarheid. In alle twintig bijdragen gaat het om eerder gepresenteerd of gepubliceerd werk dat (soms in bewerkte of vertaalde vorm) wordt afgedrukt. De oudste publicatie dateert uit 1856 en negen artikelen zijn geschreven voor 2006.

In de inleiding wordt Life Writing omschreven als 'biographical research in the broadest sense of the word' (3). De Canadese hoogleraar Marlene Kadar, die volgens de redacteuren het beste over Life Writing heeft geschreven, komt in haar bijdrage (uit 1992) met drie omschrijvingen. Life Writing kan worden gezien als equivalent van de biografie, met aandacht voor autobiografische geschriften. Daarnaast is het mogelijk dit begrip te beschouwen als "writing about the "self" or the "individual"” (298) en tenslotte kan het 
als kritische en emancipatoire praktijk over het schrijven van het individu worden gezien. Ook De Haan maakt in zijn stuk (uit 2010) duidelijk dat diverse academische centra en wetenschappers verschillende omschrijvingen hanteren. Desondanks is het volgens hem wel mogelijk om algemene karakteristieken te geven. Life Writing zou zich minder op de historische context richten en meer op egodocumenten, hecht veel aandacht aan het schrijfproces en de rol van de onderzoeker zelf en Life Writing kan emancipatorisch werken. Life Writing komt voort uit Cultural Studies en heeft sterke invloeden ondergaan van bijvoorbeeld vrouwenstudies en postkoloniale studies.

Renders is in diverse bijdragen stelliger in zijn afwijzing van Life Writing. Life Writers werken interdisciplinair, zijn ideologisch gemotiveerd en werken eerder vanuit een therapeutische dan een academische houding. Door hun aandacht voor de underdogs van deze wereld willen ze volgens hem de geschiedenis herschrijven. Hun focus op egodocumenten doet de aandacht voor de (historische) context naar de achtergrond verdwijnen. Erger nog: ze geven soms publiekelijk aan een hekel te hebben aan de harde feiten als die niet in hun straatje van pas komen. Deze aantijgingen vragen om een onderbouwing. Welke auteurs bezondigen zich hieraan? Hier blijft Renders in gebreke door vrijwel nergens man, vrouw en paard te noemen.

Waar een eensluidende definitie van Life Writing ontbreekt, is er eveneens geen helderheid over het begrip biografie. Volgens Renders en De Haan is een biografie 'the study of the individual, based on the methods of historical scholarship, with the goal of illuminating what is public, explained and interpreted in part from the perspective of the personal' (2). Maar de bundel maakt tegelijkertijd duidelijk dat die omschrijving niet voldoet. Biografieën gaan namelijk niet uitsluitend en alleen over personen, maar kunnen bijvoorbeeld ook een gebouw of straat als onderwerp hebben. In de appendix citeert Renders bovendien instemmend Klaas van Berkel die stelde dat de biografie een methode is. Dit is toch iets anders als 'the study of the individual, based on the methods of historical scholarship'. En elders schrijft Renders weer dat 'a biography is not so much the story of a life, but of a legacy' (326).

Naast kritiek op bestaande praktijken wil de bundel een nieuwe vorm van microhistory als inspiratiebron voor biografen presenteren. Daartoe geeft de Finse hoogleraar sociale geschiedenis Matti Peltonen een historisch overzicht over de opkomst van microhistory. Ook wordt een artikel van de vooraanstaande Italiaanse historicus Carlo Ginzburg, een van de founding fathers van microhistory, herdrukt. Wat de nieuwe benadering volgens Renders en De Haan nu zo aantrekkelijk maakt, is niet alleen het uitgebreide bronnengebruik en het vermeende niet-ideologische karakter, maar ook blootleggen 'wie es eigentlich gewesen' zou zijn: 'By means of biographical research on a person, one attempts to determine the extent to which the accepted story about a culture is correct' (10). Maar wat deze nieuwe microhistory biografen concreet te bieden heeft, wordt nauwelijks uitgewerkt.

Een van de vragen die microhistorici bezig houden, is de vraag naar de representativiteit. Vertegenwoordigt een individu een specifieke groep, of is hij of zij juist 
een uitzondering? Om dit te kunnen beoordelen, is grondige kennis van de historische omgeving van een vrouw of man noodzakelijk. Hier komen we op het terrein van hetgeen Renders de opdracht van een goede biograaf vindt: een persoon in haar of zijn omgeving plaatsen en aangeven wat het persoonlijke voor het publieke leven betekent. Opvallend is dat dit laatste onderdeel van zijn pleidooi niet gepaard gaat met een analyse van wat nu het persoonlijke is of zou kunnen zijn. Hierover is nu juist het nodige te zeggen. Wat maakt iets privé, of publiek, en is dat onderscheid wel altijd scherp te maken? Dit is een kwestie waar biografen meer over zouden moeten reflecteren.

Concluderend wil ik stellen dat de aanval op Life Writing mij niet overtuigt door de karikatuur die hier soms van gemaakt wordt. Het lijkt mij voor de wetenschappelijke beoefening van de biografie weinig productief deze wat gekunstelde strijd verder op te voeren en piketpaaltjes te slaan tussen Life Writing en de biografie. Er zijn voor biografen genoeg andere uitdagingen, zoals de ontwikkeling van e-humanities en transnationale perspectieven. De duidelijkheid die de bundel wil verschaffen, komt bovendien onvoldoende uit de verf door het ontbreken van heldere en eenduidige definities van de kernbegrippen. De pretentie van een handboek wordt niet waar gemaakt.

Tot slot nog een opmerking over de prijs. Zeker omdat diverse artikelen via JSTOR beschikbaar zijn, is een bedrag van 152,95 dollar voor een eenvoudig uitgegeven paperback aan de forse kant.

Margit van der Steen, Radboud Universiteit Nijmegen en Huygens ING 
Onno Sinke, Loyaliteit in verdrukking. De Technische Hogeschool Delft tijdens de Bezetting (Amsterdam: Boom, 2012, 264 pp., ISBN 978946105224 7).

Over de Nederlandse universiteiten tijdens de Duitse bezetting is de afgelopen twintig jaar een interessant rijtje studies verschenen: Peter Jan Knegtmans schreef over de Universiteit van Amsterdam (1998), Gjalt Zondergeld over de Vrije Universiteit (2002), Sander van Walsum over de Universiteit Utrecht (1995) en Klaas van Berkel over Groningen (2005). Aan dat rijtje kan nu Loyaliteit in verdrukking. De Technische Hogeschool Delft tijdens de Bezetting van Onno Sinke worden toegevoegd. De auteur promoveerde in 2009 op een studie over Radio Oranje.

Sinke voegt zich daarmee in een interessant, maar enigszins verscheurd gezelschap. Knegtmans, Zondergeld, Caljé en Van Berkel vlogen elkaar enige jaren geleden op de pagina's van dit blad (121:2 (2006)) in de haren naar aanleiding van de publicatie van Van Berkels boek (Academische illusies, 2005), veruit de omvangrijkste van deze studies. Het belangrijkste twistpunt was waar zo'n boek eigenlijk over zou moeten gaan. Is dit allereerst universiteitsgeschiedenis? Of vooral bezettingsgeschiedenis?

Van Berkel wilde nadrukkelijk universiteitsgeschiedenis schrijven, en koos zijn tijdsperiode niet voor niets ruim: 1930-1950. Die periode wordt in zijn visie gekenmerkt door verlangen naar het ideaal van de academische gemeenschap, waarin de student niet alleen werd geschoold, maar ook zedelijk gevormd. Dat ideaal stond onder druk door de wassende stroom studenten die vooral kwamen om een vak te leren. Het speelde volgens Van Berkel een grote rol in de morele dilemma's van de bezetting: wie de universiteit zag als morele gemeenschap was minder compromisbereid dan wie haar allereerst zag als opleidingsinstituut. Hij pleitte daarmee, zoals P.J. Caljé vaststelde, voor 'historisering van de moraal'.

Zondergeld daarentegen meende dat de omstandigheden van de bezetting zó hard en diep ingrepen dat er tussen 1940 en 1945 niets anders bestaat dan bezettingsgeschiedenis. De dilemma's waarmee studenten en docenten werden geconfronteerd hadden met de universiteitsgeschiedenis eigenlijk niet zoveel te maken, maar draaiden om die aloude en volgens Zondergeld nog altijd bruikbare tegenstelling: goed tegenover fout; verzet tegenover aanpassing dan wel collaboratie.

Waar plaatst Sinke zich in dit spectrum? Expliciet nergens, is het eerste antwoord. Sinke begint niet met enige historiografische plaatsbepaling, ook niet ten opzichte van de 
bestaande geschiedschrijving over Delft, zoals H. Baudets De lange weg naar de Technische Universiteit uit 1992. Hij kiest voor verhalende geschiedschrijving en trekt de lezer direct vakkundig de gebeurtenissen binnen: 'Het was vroeg in de ochtend en ongewoon druk op straat'. Ook in zijn conclusies laat hij het debat grotendeels voor wat het is. Ondertussen werpt zijn boek daar wel degelijk licht op, en maakt Sinke natuurlijk wel impliciete keuzes.

Wat de tegenstelling universiteitsgeschiedenis-bezettingsgeschiedenis betreft doet Sinke een beetje van beide. Dat vloeit ook voort uit zijn verhalende aanpak. Hij wil de lezer een indruk geven van de manier waarop de oorlog ingreep in het leven van Delftse docenten en studenten. Zo beschrijft hij uitgebreid de sabotageacties van de groep rond Willem Pahud de Mortanges en hun dood voor het vuurpeloton of de belevenissen van in Duitsland tewerkgestelde Delftse studenten. Met de Technische Hogeschool (TH) heeft dat eigenlijk weinig van doen. Hier heeft het boek het nadeel dat ook veel lokale bezettingsgeschiedenissen aankleeft: het is deels het bekende verhaal van de oorlog, alleen met andere namen en gezichten. Verhaaltechnisch is dat een begrijpelijke keuze, maar wetenschappelijk gezien zet het weinig zoden aan de dijk.

Interessanter zijn de reacties van studenten en docenten op maatregelen die direct de Hogeschool betroffen. Twee van die maatregelen bepaalden de geschiedenis van de TH: de schorsing (later gevolgd door het ontslag) van Joodse medewerkers in november 1940, en de voor alle studenten verplichte ondertekening van de loyaliteitsverklaring in april 1943. De reactie op die twee maatregelen was paradoxaal, zegt Sinke: in november 1940 reageerden de Delftse studenten principieel, door in staking te gaan. Dat gebeurde verder alleen in Leiden. In april 1943 daarentegen tekende ruim $26 \%$ van hen de loyaliteitsverklaring, bijna twee keer zoveel als het landelijk gemiddelde. En de Delftse senaat, de vergadering van hoogleraren, was de enige in het land die de studenten aanraadde zo te handelen.

Beide gevallen illustreren het dilemma van de bezetting: pragmatisme versus principe. Dat de schorsing van Joden een schande was, daarover was iedereen het eens scheikundige prof. A.J. Kluyver noemde het tegenover zijn collega's de ernstigste gebeurtenis uit de geschiedenis van de Hogeschool. De vraag was alleen of protest niet meer kwaad dan goed zou doen. De hoogleraren, zowel in Delft als elders, vreesden dat studentenprotesten zouden leiden tot sluiting van het hoger onderwijs en wellicht zelfs tot doden onder de studenten - zoals in Polen was gebeurd. Hun zorg was om de studenten - wier verontwaardiging zij deelden - af te houden van onbezonnen stappen. In Leiden deed R.P. Cleveringa dat door in zijn beroemd geworden rede enerzijds de schorsing te hekelen en anderzijds de studenten op te roepen geen 'nutteloze dwaasheden' te begaan. In Delft besloten de hoogleraren zich stil te houden; niemand protesteerde.

Het resultaat was in beide gevallen hetzelfde: de studenten staakten en de $\mathrm{TH}$ werd net als de Leidse universiteit gesloten. De laatste bleef dicht, de TH ging voorjaar 1941 weer open. Rector magnificus C.J. van Nieuwenburg peperde de studenten bij die 
gelegenheid in dat 'wij de politiek buiten de muren van de Technische Hogeschool moeten trachten te houden'. Voor de toekomst van het land, zo meende hij (en bijna alle hoogleraren), was de TH onmisbaar. Dus moest zij openblijven.

Maar niet tegen elke prijs. Toen de Duitsers in april 1943 in reactie op groeiend verzet uit studentenkringen in één klap de universiteiten wilden onderwerpen door van alle studenten een loyaliteitsverklaring te eisen, achtten de Delftse hoogleraren dat aanvankelijk een gewetenskwestie die de studenten zelf moesten beslissen. Hun uiteindelijke advies om toch te tekenen was, naar het lijkt, een gevolg van een opmerkelijke interventie van de natuurkundige prof. E.C. Wiersma. In een gloedvol pleidooi stelde hij dat de Nederlandse zaak veel meer geschaad werd door beëindiging van de studie en dwangarbeid in Duitsland dan door een handtekening waar men zich verder niet aan gebonden hoefde te achten. Omdat Wiersma diep in het verzet zat, lieten veel collega's zich overtuigen, en adviseerde de senaat de studenten te tekenen. Met als gevolg dus een relatief hoog percentage tekenaars.

Deze opmerkelijke gang van zaken toont al aan dat niet alle dilemma's van de bezetting helder waren, zoals Zondergeld wil. En het bevestigt Van Berkels conclusie dat tekenen of niet-tekenen na de oorlog ten onrechte werd gehanteerd als lakmoestest van vaderlandsliefde. Van Berkel zag dat als een laatste poging van de aanhangers van de civitas academica, in casu corpsstudenten met een verzetsverleden, om het ideaal van een morele gemeenschap af te dwingen. Of dat in Delft ook zo is, laat Sinke in het midden, hoewel zijn beschrijving van de zuivering lijkt op die van Van Berkel.

Door de verhalende aanpak en bescheiden omvang levert Sinkes boek een veel kleinere bijdrage aan de geschiedenis van het universitair onderwijs tijdens de bezetting dan de studies van Knegtmans of Van Berkel. Maar vergeleken met Zondergeld toont hij een weldadig begrip voor de overlappende en conflicterende loyaliteiten: aan de hogeschool, aan de studentenvereniging, aan de idealen van de rechtsstaat of aan de ouders die hadden gesappeld om een studie mogelijk te maken.

Bart van der Boom, Universiteit Leiden 


\section{Luuc Kooijmans, Het orakel. De man die de geneeskunde opnieuw uitvond: Herman}

Boerhaave (1668-1738) (Sleutelfiguren 2; Amsterdam: Balans, 2011, 392 pp., ISBN 97894 $60033445)$.

Heel lang is Herman Boerhaave een held van de Nederlandse wetenschap geweest en misschien is hij dat nog steeds wel. Die heldenstatus had de Leidse hoogleraar in de botanie, geneeskunde en scheikunde al in de achttiende eeuw en in de moderne geschiedschrijving is deze nog eens bevestigd door het werk van de medisch historicus G.A. Lindeboom. Niet voor niets heet ons nationale museum voor de geschiedenis van de natuurwetenschappen en de geneeskunde in Leiden Museum Boerhaave. Toch valt moeilijk uit te leggen waar die canonieke status van Boerhaave precies op berust. Zijn naam is niet verbonden met een doorbraak in de medische wetenschap of in de scheikunde - de twee vakgebieden waarop hij het meest actief is geweest - en zijn reputatie als initiator van het onderwijs aan het ziekbed is de laatste jaren behoorlijk gerelativeerd. Hij was niet de eerste die het deed, hij deed het niet systematisch en na hem raakte deze moderne vorm van medisch onderwijs al weer snel in onbruik. Er was dus alle ruimte voor een nieuwe interpretatie van leven en werk van Boerhaave en het feit dat Luuc Kooijmans zijn biografie als ondertitel meegaf 'de man die de geneeskunde opnieuw uitvond' maakt nieuwsgierig.

De lezer wordt niet teleurgesteld. Met vaardige pen leidt Kooijmans ons door de verschillende fasen van het leven van Boerhaave. Hij heeft een goed oog voor het sprekende detail en weet in eenvoudige bewoordingen uit te leggen wat de wetenschappelijke opvattingen waren waar Boerhaave zich tegen afzette of waar hij zich juist voor inzette. De kenner zal misschien hier en daar de voorstelling van het cartesianisme of het spinozisme wat al te schematisch vinden, maar voor de grote lijn is dit allesbehalve bezwaarlijk. Goed uit de verf komt hoe de Leidse universiteit, waar Boerhaave zijn hele leven lang trouw aan is gebleven, een bijenkorf was waar interessante jongelieden uit alle windstreken in en uit vlogen, daarbij steeds de grote Boerhaave de hem toekomende aandacht schenkend. Boerhaave voelde er nooit voor zich te verbinden aan het hof van Willem III of welke andere vorst dan ook. Hij was wars van pretenties, had een hekel aan vormelijkheid en kleedde zich gewoontjes. Aan een hof zou hij zich zeer ongelukkig hebben gevoeld. Maar hij had zo'n hof ook helemaal niet 
nodig om in contact te komen met interessante mensen. Voor hem was de universiteit van Leiden de ideale omgeving om in alle eenvoud een boeiend leven te leiden.

Een klein bezwaar tegen dit overtuigend neergezette beeld van Boerhaave is wel dat Kooijmans het zijn lezers niet makkelijk maakt na te gaan waar hij zijn gegevens precies vandaan heeft. Het boek kent geen voetnoten, alleen aan het eind een aantal ongenummerde, per hoofdstuk gegroepeerde losse opmerkingen die met enig geblader wel aan bepaalde opmerkingen in de tekst te koppelen zijn. Maar de precieze plaats waar een citaat te vinden is, wordt niet gegeven, zodat het voor mij bijvoorbeeld niet mogelijk was na te gaan of de opmerking van Johan Bernoulli over 'mes theologiens persecuteurs' (112) nu slaat op de hoogleraren theologie in Groningen of op de hardliners in Bazel. Kennelijk heeft de auteur (of de uitgever) gedacht dat het opnemen van voetnoten het boek onaantrekkelijk maakt voor de algemene lezer en dat wetenschappelijkheid daarom maar moest wijken voor leesbaarheid. Jammer dat de wetenschappelijke redactie van de serie waarin dit boek verschijnt (de Sleutelfiguren-reeks van het Prins Bernhard Cultuurfonds) dit heeft laten passeren. Merkwaardig is overigens weer wel dat citaten in het Duits, Engels of Frans onvertaald blijven. De algemene lezer wordt kennelijk geacht moeiteloos een lang Frans citaat tot zich te kunnen nemen, maar lichtelijk onpasselijk te worden bij het zien van een eenvoudig cijfertje dat verwijst naar een notitie waarin precies staat waar dat citaat vandaan komt.

Maar belangrijker natuurlijk dan dit soort muggenzifterij is de vraag wat het nu betekent dat Boerhaave de geneeskunde opnieuw uitvond. Wat was het nieuwe van de geneeskunde zoals Boerhaave die bedreef, wat was zijn 'uitvinding' op dit vlak? Al vroeg in zijn carrière was Boerhaave tot de overtuiging gekomen dat er in de geneeskunde dringend behoefte was aan een nieuw theoretisch kader, een nieuw samenhangend systeem - aan een nieuwe Galenus (46). Maar dan niet Galenus de systeembouwer met een neiging tot speculatie, maar iemand als Hippocrates, de nauwkeurige waarnemer, de ware held van Boerhaave (73). Verder lezen we weer dat de essentie van Boerhaaves bijdrage aan de geneeskunde lag in de combinatie van empirische wetenschappelijk grondslag, samenhang en heldere presentatie. 'Hij verkondigde niets dat niet al eens eerder was beweerd' (79). Een heldere presentatie betekende overigens vooral veel schrappen, want in de loop der eeuwen hadden filosofen en geneeskundigen allerlei elementen aan de geneeskunde toegevoegd die het zicht op de ware geneeskunde alleen maar belemmerden: humeuren, fermenten, onzichtbare poriën, aangeboren warmte en andere speculatieve concepten van galenische of cartesiaanse huize (109). Eenvoud, daar ging het om, een van speculatie gezuiverde en op ervaring gestoelde geneeskunde in de stijl van Hippocrates (81). Dat was meer dan alleen pretentie en programma. Boerhaaves handboek voor de scheikunde, zijn Elementa chemiae uit 1731, was ook werkelijk een heroïsche poging in de scheikunde feit en fictie te scheiden en alles wat overbleef op systematische wijze te ordenen, veel systematischer dan voorheen (262-263). In dit schiftings- en ordeningsproces zagen ook tijdgenoten de verdienste van Boerhaave. La Mettrie die in 1733 onder Boerhaaves gehoor zat, vond dat hij door de geneeskunde een 
natuurwetenschappelijke basis te geven orde had geschapen in de chaos waarin het vak zich rond de eeuwwisseling had bevonden en dat hij zo had gedaan wat Descartes in de filosofie had gedaan $(273,286)$. La Mettrie, was echter vooral onder de indruk van Boerhaave als docent: 'Quelle facile et brillante élocution! Un seul geste exprimoit la chose avant qu'il l'eut dire [...] Quelle clarté dans ses demonstrations!' (285). Boerhaave dus als de hoogleraar die de nieuwe natuurwetenschappelijke geneeskunde die anderen al hadden uitgedacht nu ook doceerbaar maakte. Is dat dan de nieuwe geneeskunde die Boerhaave had uitgevonden? Ik vrees dat dit inderdaad de basis van de roem van Boerhaave is geweest, tot in de negentiende en twintigste eeuw toe. In dat opzicht vertelt Kooijmans ons niets nieuws. Maar Boerhaave had zelf liever gezien dat hij zou voortleven als degene die een belangrijke doorbraak in de scheikunde had bewerkstelligd. Dat zou pas werkelijk een nieuwe geneeskunde hebben opgeleverd, hoe nuttig het ordenen van wat anderen al hadden ontdekt ook was.

Klaas van Berkel, Rijksuniversiteit Groningen 
Diederick Slijkerman, Het geheim van de ministeriële verantwoordelijkheid. De verhouding tussen koning, kabinet, Kamer en kiezer, 1848-1905 (Dissertatie Leiden 2011; Amsterdam: Bert Bakker, 2011, 467 pp., ISBN 978903513704 2).

De hoofdthese van het proefschrift van Diederick Slijkerman luidt dat de ministeriële verantwoordelijkheid historisch niet als een regel of als een statisch begrip moet worden gezien, maar als een dynamisch begrip waarvan de interpretatie veranderde naar gelang de machtsverhoudingen tussen de vier constitutionele machten: koning, kabinet, Kamer en kiezer. Wanneer het kabinet de overhand had, kreeg de ministeriële verantwoordelijkheid een andere inhoud en reikwijdte dan wanneer het overwicht bij de Kamer lag. Slijkerman laat de ontwikkeling van het begrip zien aan de hand van zes momenten: de grondwetsherziening van 1848 , de Aprilbeweging van 1853 , de conflicten tussen een conservatief kabinet en een liberale Kamermeerderheid in 1866 en 1867, de opvolgingskwestie van 1884 en de formalisering van het premierschap in 1901. De laatste twee onderwerpen krijgen aanzienlijk minder aandacht dan de eerste vier. De ministeriële verantwoordelijkheid wordt niet als geïsoleerd begrip behandeld, maar in samenhang met onder andere de vertrouwensregel, de homogeniteit van het kabinet, dualisme en monisme, en het ontbindingsrecht.

Slijkerman laat overtuigend zien dat de interpretatie van de ministeriële verantwoordelijkheid niet hetzelfde bleef na de herziening van de Grondwet in 1848 . Aanvankelijk was deze nog nauwelijks omschreven. De Grondwet verklaarde de koning onschendbaar maar kende hem wel bepaalde machten toe als het hoogste gezag over het leger en het recht de Kamer te ontbinden. Of en in hoeverre de ministeriële verantwoordelijkheid zich tot deze gebieden uitstrekte, bleef aanvankelijk onduidelijk. De tendens was wel dat steeds meer zaken onder de ministeriële verantwoordelijkheid vielen, waardoor de eigen macht van de koning steeds geringer werd. Zo probeerde Thorbecke volgens Slijkerman in 1853 de speelruimte van de koning in te perken en werd tijdens de crisis van 1866 en die van 1867 het dualisme van 1848 vervangen door het monisme. De Kamer bepaalde toen dat de ministeriële verantwoordelijkheid absoluut was, dat wil zeggen dat geen enkel onderwerp of terrein zich daaraan onttrok. Ook de macht van het kabinet werd ingeperkt doordat de Kamer sindsdien zonder nadere motivatie het vertrouwen kon opzeggen. Slijkerman bestrijdt overigens de opvatting dat 
de vertrouwensregel pas in 1866 en 1867 vaste voet aan de grond kreeg. Volgens hem gold die al vanaf de herziening van 1848.

Slijkerman constateert terecht dat de liberale opvattingen over de bevoegdheden van koning, Kamer en kabinet verschoven en dat die verschuivingen in 1866 en 1867 in dienst stonden van doodgewone machtspolitiek. Het is goed dat dit weer eens naar voren wordt gebracht. Tegenwoordig wordt nogal eens uit het oog verloren dat, hoe interessant vertogen en vormen van politiek ook mogen zijn, het ook gewoon om de knikkers ging. Juist in politieke geschiedenis mag de machtsvraag niet uit het oog worden verloren.

Naast de onmiskenbare verdiensten van het proefschrift telt het helaas ook nogal wat onvolkomenheden. Een eerste tegenvaller is dat het boek meer belooft dan het biedt. Van de ongeveer 390 pagina's gaan ongeveer tien over de kiezer, hoewel deze in de inleiding als één van de vier constitutionele machten wordt gepresenteerd. En in die tien pagina's gaat het dan eigenlijk vaak nog niet eens over de kiezer, maar over de pers. Slijkerman meent namelijk de opvattingen onder de kiezers te kunnen onderzoeken door het raadplegen van kranten. 'De dagbladen waren de spreekbuis van bepaalde groepen kiezers omdat zij verbonden waren aan bepaalde levensbeschouwelijke stromingen' (29). Moet ik hieruit afleiden dat Slijkerman meent dat Nederland tussen 1848 en 1870, waarover het overgrote deel van zijn boek handelt, een verzuilde samenleving was?

Maar Slijkerman gaat nog verder. Hij meent dat de dagbladen representatiever waren voor de opvattingen van het volk dan de opvattingen van de kiezers doordat ze toegankelijker waren (307-308). Het is mij niet duidelijk wat hij hier precies bedoelt. Dat de opvattingen van het volk meer tot uitdrukking kwamen in de kranten dan in het stemgedrag van de kiezers? Dit is wel een heel achterhaalde opvatting over de samenstelling van het kiezerskorps. Veel kiezers waren bakkers, slagers en kleine boeren en talloos zijn de klachten over de kiezers die nauwelijks in staat waren de naam van de kandidaat op het stembiljet te schrijven. Die kiezers zullen bepaald niet bijgedragen hebben aan de opinie van bijvoorbeeld de Nieuwe Rotterdamsche Courant. Waarschijnlijk hebben ze die krant ook nooit in handen gehad, omdat die tot de afschaffing van het dagbladzegel in 1869 veel te duur was. Het lezerspubliek van de dagbladen was veel elitairder, hoger opgeleid en vermogender dan de gemiddelde kiezer. Ik kan mij niet aan de indruk onttrekken dat Slijkerman zich in deze materie slecht heeft ingelezen.

Daarnaast zijn er de soms opmerkelijke interpretaties van teksten. Zo kan de koninklijke proclamatie die in 1866 werd verspreid volgens Slijkerman niet beschouwd worden als een koninklijk partij kiezen voor het conservatief kabinet (192). Dat lijkt me toch moeilijk vol te houden als we in de proclamatie lezen dat Willem III de Kamer heeft ontbonden, omdat tussen de Kamer en de regering overeenstemming ontbreekt en 'dat die overeenstemming en zamenwerking niet te verkrijgen zijn met de jongste zamenstelling van de Tweede Kamer der Staten-Generaal'. Dat lijkt me in de context van de heftige partijstrijd die zich in de Kamer afspeelde en die Slijkerman zelf aanvoert als een van de oorzaken van de crisis van 1866 een weliswaar netjes geformuleerde maar 
toch heel duidelijke aanmaning om conservatieve kandidaten te kiezen. Dat die tekst ook zo was bedoeld, blijkt ook hieruit dat de proclamatie tegelijk met de stembiljetten naar de kiezers werd gestuurd.

Even merkwaardig is de weergave rond het ontslag van het kabinet-Thorbecke in 1853. Het kabinet verkeerde in de veronderstelling (of dat terecht of onterecht was, is hier niet relevant) dat Willem III in Amsterdam tijdens een toespraak zich tegen de Grondwet had gekeerd. Het kabinet was van mening dat een dergelijk groot verschil van inzicht tussen kabinet en koning niet kon voortbestaan en gaf Willem III de keuze: of een verklaring waaruit zijn homogeniteit met het kabinet bleek of het kabinet ontslaan. De koning koos voor het laatste. Slijkerman citeert keurig de brief waarin het kabinet Willem III voor de keuze stelt (116), maar nu gebeurt er iets merkwaardigs. Gaandeweg het relaas verandert de weergave. Op pagina 145 heet het dat Thorbecke in 1853 de koning de wet probeerde voor te schrijven, op pagina 149 eiste het kabinet openlijk excuses van Willem III en op pagina 152 moest de koning zich volgens Thorbecke zonder eigen manoeuvreerruimte achter het kabinet opstellen. Wat is er hier nog over van de vrije keuze die Thorbecke de koning in de kabinetsbrief liet? Deze verschuiving is typerend voor de casus over 1853, waarin het lijkt alsof Slijkerman hoe dan ook wil aantonen dat Thorbecke toen al van zijn dualisme aan het afstappen was, maar hij overtuigt niet.

Deze interpretaties en het gebrek aan literatuurkennis, zoals hierboven bij het onderwerp kiezer en kranten, kunnen helaas nog met andere voorbeelden worden aangevuld. Ze doen veel afbreuk aan het proefschrift en dat is jammer, want Slijkerman heeft veel wetenswaardigs te vertellen over de ontwikkeling van de ministeriële verantwoordelijkheid.

Ron de Jong, Kiesraad 
Jouke Turpijn, 80's Dilemma. Nederland in de jaren tachtig (Amsterdam: Bert Bakker, 2011, 255 pp., ISBN 978903513480 5).

Onder historici neemt de belangstelling voor de laatste decennia van de twintigste eeuw toe, zowel in Nederland als elders. Dat heeft onder meer geleid tot een groeiend aantal 'decennia-studies', met name over de jaren zeventig, maar inmiddels hebben ook de jaren tachtig de nodige aandacht gekregen. Jouke Turpijns boek 80's Dilemma (een taalkundig wonderlijke titel overigens) is een interessant voorbeeld van deze belangstelling.

Afgezien van een inleiding en conclusie bestaat het boek uit vier hoofdstukken. In hoofdstuk twee gaat Turpijn vooral in op de Haagse politiek. Hij behandelt daarin de groeiende betekenis van de televisie en de daarmee samenhangende verpersoonlijking van het politieke bedrijf. In de jaren tachtig ging het steeds minder om standpunten, maar om de vraag of 'je kunt scoren in de publiciteit' (55). Politiek-ideologische verschillen werden minder belangrijk; verkiezingscampagnes werden steeds saaier, de debatten in de Tweede Kamer voorspelbaar. 'De politiek van macht, media en zakelijk onderhandelen won het dus van het bevlogen idealisme en het heilige gelijk' (56). De CDA-politicus Ruud Lubbers, 'een ultiem berekenende en van ideologie onthechte geest' (71), vormde in velerlei opzicht de verpersoonlijking van deze ontwikkeling. Er werd echter wel een prijs betaald voor de nieuwe zakelijkheid: de burgers begonnen zich van de Haagse politiek af te wenden.

Vervolgens komt de wereld van het activisme aan de orde. In de jaren tachtig heersten teleurstelling, scepsis en cynisme onder de actievoerders. Vele activisten trokken zich uit de politieke arena terug; sommigen (vooral krakers) radicaliseerden en gingen over tot geweld. Tegelijkertijd ontstonden evenwel nieuwe vormen van (veeleer rechts georiënteerd) 'vrije-jongens'-activisme. Turpijn verwijst in dit verband naar de opkomst van etherpiraten, die zich vaak een opvallende populariteit wisten te verwerven, en naar voetbalhooligans. Het lijkt merkwaardig om deze op één lijn te stellen met krakers en andere politieke activisten. Maar Turpijn beschouwt hun activiteiten allemaal als vormen van avontuurlijk, tegen het gezag gericht, gedrag: 'autonomen, piraten, onthechte jongeren en voetbalvandalen [waren] allen, en soms zelfs alleen maar, op zoek naar avontuur' (115).

In hoofdstuk vier komt de economie aan de orde, met name de massawerkloosheid. Vooral onder jongeren was de werkloosheid groot, waardoor de 
jaren tachtig nog vaak worden geïdentificeerd met 'een verloren generatie' en doemdenken. En niet geheel ten onrechte. Ondanks alle goede bedoelingen leverden pogingen de jeugdwerkloosheid te bestrijden, zoals de Experimentele Arbeidsprojekten voor Jeugdige Werklozen, in het algemeen niets op. Oppositie en protest tegen de werkloosheid hadden weinig resultaat. Turpijn wijdt dat vooral aan het in 1982 door de Federatie Nederlandse Vakbeweging (FNV) en werkgevers gesloten Akkoord van Wassenaar, waarin loonmatiging werd geruild tegen arbeidstijdverkorting. Toch was het in de jaren tachtig niet alleen kommer en kwel. 'Baanlozen' experimenteerden met nieuwe werkvormen. Sommigen deden vrijwilligerswerk, anderen begonnen voor zichzelf.

Ten slotte komen in hoofdstuk vijf cultuur en engagement aan bod. Turpijn wijst op de afnemende politieke betrokkenheid, de groeiende scepsis, en uiteindelijk zelfs 'leegheid' onder kunstenaars. Dat betrof onder meer de popmuziek, dit ondanks mediaspektakels als Live Aid (voor het hongerende Ethiopië). Er kwam een einde aan het streven naar 'vernieuwing'. Turpijn beschouwt A.F.Th. van der Heijden en Joost Zwagerman als de belangrijkste literaire chroniqueurs van het ook in de kunstwereld heersende cynisme. Kunstenaars zochten in de eerste plaats persoonlijk succes en individueel vermaak. En zij waren niet de enigen. 'Veel Nederlanders omarmden eind jaren tachtig de gedachte dat het materialisme het wijd en zijd van het engagement gewonnen had' (185). Ter illustratie van deze ontwikkeling gaat Turpijn onder meer in op de opkomst en vooral ondergang van het Nicaragua Komitee Nederland.

Al met al vormden de jaren tachtig een periode van radicale politieke transformatie. Er was sprake van een 'verschuiving van politiek naar antipolitiek, van betrokkenheid naar vervreemding en van open dissensus naar gesloten consensus' (14). Om deze ontwikkeling te duiden maakt Turpijn gebruik van het begrippenpaar GesinnungVerantwortung. Er vond in de jaren tachtig volgens Turpijn een ingrijpende verandering plaats in het politieke denken en handelen, van Gesinnungsethik naar Verantwortungsethik. Deze ontwikkeling plaatste vele burgers voor een ethisch dilemma (vandaar de boektitel 80's Dilemma) 'tussen de totaalpolitiek van Gesinnung, waarin een actor in principe alles geeft om doelen te verwezenlijken, en de gereductioneerde voorstelling van Verantwortung, waarin een actor vooral iets komt halen en eventuele onderhandelingen zo zakelijk mogelijk ingaat en over zo min mogelijk laat gaan' (16).

Deze wel erg zwaar aangezette (en aanvechtbare) toepassing van de begrippen Gesinnung en Verantwortung is niet echt verhelderend. In de beschrijvende hoofdstukken komt een heel scala aan opvattingen en gemoedstoestanden aan de orde. De jaren tachtig, zo concludeert Turpijn zelf, waren 'geen grijze brij' waarin 'idealisme' en 'kritisch burgerschap' louter afstierven. Ze vormden 'een vlek van neonkleuren' (203). Door het gebruik van de genoemde termen worden bepaalde opvattingen en personages bovendien soms wel heel makkelijk ingedeeld. Was het beleid van de eerste twee centrumrechtse kabinetten-Lubbers (privatisering, deregulering, marktwerking, herstel gezin) louter 'ideologisch onthechte' pragmatiek? En was PvdA-leider Joop den Uyl 'in tegenstelling tot Lubbers' inderdaad 'één en al visionair' (66)? 
Turpijns 80's Dilemma is vlot geschreven, maar het streven vooral een luchtig en prikkelend boek te willen maken heeft afbreuk gedaan aan de analytische helderheid en vaak ook aan de taalkundige zorgvuldigheid. Zo wordt in de inleiding opgemerkt dat veel mensen vanwege hun 'behoefte aan geschiedenis' op zoek zijn naar 'observatiepunten in het verleden die uitzicht geven over het oerwoud van de tijd' (7). 'De analyses en bronnen in dit boek vormen een touwbrug tussen twee kloven', zo staat verderop (31). Jammer dat Turpijn nauwelijks vergelijkt met ontwikkelingen elders. Wat zich in Nederland afspeelde was immers bepaald niet uniek. Dat neemt niet weg dat de beschrijvende hoofdstukken genoeg informatieve en interessante observaties bevatten. Degenen die geïnteresseerd zijn in de jaren tachtig van de twintigste eeuw doen er dan ook goed aan 80 's Dilemma ter hand te nemen.

Duco Hellema, Universiteit Utrecht 
Monica Stensland, Habsburg Communication in the Dutch Revolt (Amsterdam Studies in the Dutch Golden Age; Amsterdam: Amsterdam University Press, 2012, 235 pp., ISBN 978 $9089644138)$.

Up until the seventies of the previous century, the research concerning the Dutch Revolt focused on the rebellion against Spanish polities in the Netherlands. Thereafter, the loyal opposition, the rituals and the representation of power and repression as well as the peace making in the years 1565-1598 became the object of study. Pamphlets that had appeared between 1566 and 1584 had already been object of research. A study of the Spanish Habsburg discourse, however, was until recently lacking.

In Habsburg Communication in the Dutch Revolt, based on the doctoral dissertation of the author presented at Oxford University in 2008, Monica Stensland addresses the vision on government, politics and warfare in the Netherlands as they were discussed by the government and the royalists between 1567 and 1609, i.e. from the arrival of the Duke of Alba in the Netherlands until the Twelve Years' Truce. Stensland is well aware that the word 'propaganda' is so unsuited to early modern realities, but she very deliberately chooses not to talk about polemic publications. These, indeed, suppose an open and forthright debate, and that did not take place. Therefore, the author chooses to speak about 'public communication'.

The study follows a chronological order and devotes attention to public ceremonies, to sermons, to visual media such as pictures, medals and paintings, and, of course, to printed proclamations and commentaries. The nearly three hundred preserved pamphlets stemming for the period investigated constituted the main source for the study. Concerning visual media (pictures, monuments et cetera) the author has relied on literature. Archival investigations were limited. That is a pity. More information about how, in the cities of Flanders, Brabant and Holland, one dealt with announcements and 'royal' events, or how local authorities in the loyal but also in the rebellious provinces reacted to the dissimination of loyal publications, can be found in city archives and in court records. L.-P. Gachard's summeries, published in his Correspondance de Philippe II, cannot replace the formulations in the original letters.

The 'Habsburg discourse' took form from 1567, only with difficultly and rather late. It is correct to say that it only took élan after the reconciliation of the Walloon provinces 
in 1579, when with Farnese clemency became clearly a topic in the reconciliation discourse. Farnese and the royalist commentators deliberately avoided the image of the 'bad governor'. After the duke of Alba had left the Low Countries (winter 1573), but even more after the beginning of the gouvernance of Farnese (1578), the times of the Iron Duke served as a point of reference in the royalist communication. Everyone in the Netherlands associated the duke's government with war and terror. Alexander Farnese, therefore, tried everything to avoid to be compared with Alba. Hence, the picture of the Duke of Alba became even grimmer. Monica Stensland aligns herself to some degree with this practice. Incorrectly, she associates the 'criminal ordinances' of 1570, intended to improve and humanize the administration of justice and to guarantee the legal rights of those arrested, with the measures taken against rebels and religious dissidents, published around the same time. She also seems to overlook that many of Alba's ordinances were not repressive in nature and originated in his concern for good government and the protection of agriculture, trade and industry in war time.

William of Orange could count on quite a lot of sympathy in Flanders and Brabant. For Spain, during a long period this was a big problem. After 1577 there was a beginning of 'separation of minds'. While in the Union of Utrecht (1579) a number of southern provinces and cities took part, the reconciliation of the Walloon provinces, the successful military and political action of Farnese and the diabolisation of William of Orange discredited the opposition against the Spanish Habsburg politics. The Spanish Habsburg discourse, in my mind royal propaganda, played an important role in this evolution.

The years 1567-1589 in the Netherlands were very chaotic. There was not only the civil war, from which several parties tried to gain. From the beginning, the political oppositions were mingled with religious dissidence. One of the more important concerns of successive governors was to maintain the authority of the King and, where necessary, to restore it. Once the Archdukes were in power the position of the King in the Spanish Habsburg Netherlands was again ascertained. In the meantime, the unity of the Netherlands was broken, in the political as well as in the religious field. The last chapter of Stensland's study is therefore devoted to the new beginning in the years 1596-1609. The fact that Albert and Isabella directly descended from the Austrian Habsburgs and from the Dukes of Burgundy, was an important theme in the discourse. The image of the pious catholic sovereigns, that was deliberately spread during the reign of Albert and Isabella and that was also confirmed by their deeds, contributed to the flourishing of the Catholic Netherlands. Tableaux vivants and publications presented the 'good sovereigns' explicitly as bringers of peace who reigned over the Netherlands legitimately, with dignity and respect.

Monca Stensland's book reads nicely, and the research is very well situated in the new insights that the historiography of the last forty years has produced concerning opposition and rebellion, war and civil war in the Netherlands. The author demonstrates that the governors in the Netherlands were unsuccessful in convincingly communicating about their actions. Only with Farnese, there is a hero who appeals. By communicating 
about peace and reconciliation, he succeeded in creating the view that his military conquests were successes in the fight for peace in the country, and this in spite of they being accompanied, as were those of his predecessors, with plundering and violations of the royal army against the civilians and the country people. With the archdukes, peace came finally and that laid the basis for a stable government in the Netherlands' part of the Spanish Habsburg kingdom. Habsburg Communication in the Dutch Revolt makes, no doubt, an important contribution to the study of war and peace in the Netherlands from the arrival of Alva until the Twelve years' Truce.

Gustaaf Janssens, KU Leuven 
Leon van den Broeke, Hans Krabbendam, Dirk Mouw (eds.), Transatlantic Pieties: Dutch Clergy in Colonial America (The Historical Series of the Reformed Church in America, No. 76; Grand Rapids, MI: William B. Eerdmans Publishing Company, 2012, xviii + 342 pp., ISBN $9780802869722)$.

In recent years, historians have given renewed attention to European missionary endeavors, Protestant as well as Catholic, that made Christianity a genuinely global religion in the early modern period. This scholarship has moved away from the confessional perspectives of older denominational treatments to focus on cross-cultural encounters that transformed both missionaries and prospective converts. The Reformed dominees who comprise the subject of this volume should probably not be considered missionaries, since most displayed little interest (and even less success) in converting Native Americans and enslaved Africans. Nevertheless these essays, taken as a whole, capture the influences of frontier settlements and the adaptations they necessitated on Dutch Reformed pastors who followed a call to North America from the seventeenth through the nineteenth centuries.

Transatlantic Pieties consists of fourteen essays (plus an introduction) devoted to mini-biographies of Reformed pastors who labored among Dutch, English, French colonists, and their descendants, in primarily what was New Netherland, until conquered by the English in 1664. Following a chronological format, the editors grouped the essays into historical periods that correspond to stages in the development of the Reformed Church in North America. Thus, 'Pioneers' contains essays on three of the earliest minsters; 'Stabilizers' covers three pastors who negotiated schisms during the transition to English rule; 'Diversifiers' treats three divisive dominees in the seventeenth century; 'Mediators' focuses on three clergy who navigated enlightenment and revolution in the eighteenth century; and 'Successors' discusses two leaders in shaping a Reformed legacy in the nineteenth century. The volume has no central argument or thesis and most of the essays are straightforward biographies that stand on their own.

Several motifs, however, do emerge that shed light on Dutch clerical culture in North America and the Netherlands. One important theme calls attention to the connections between pastors in the Americas and the Reformed Church in the Netherlands, despite the ocean that separated them. The Amsterdam consistory, later 
the classis, had responsibility for overseeing the churches in North America. They depended on the Amsterdam church district to recruit and to approve ministers for overseas mission, to clarify points of theological and ecclesiological disputes, and to provide political support with colonial authorities. Overseas pastors often crossed the Atlantic several times for temporary returns to the patria. As a result, the Dutch Reformed character of the American churches remained central to their theology and their identity. Almost all, if not all, ministers were grounded in the Voetian theology and theocratic polity that defined Dutch Reformed pietism in the seventeenth and eighteenth centuries.

A second general pattern in the essays underscores the dedication, ability, and strong sense of vocation among pastors who labored in difficult circumstances and lived close to the edge of financial destitution. Jos van der Linde shows how Henricus Selijns (1636-1701) skillfully steered the Brooklyn congregation through the tumultuous Leisler rebellion that lasted from 1689 to 1691 . Joyce $D$. Goodfriend describes the means by which the gifted and hardworking Archibald Laidlie (1727-1779) revived the congregation in New York City and navigated linguistic divisions in the church. Yet a third theme calls attention to the colorful character of pastors who defied the stereotype of the dry, austere, and unblemished Calvinist dominee. Willem Frijhoff recalls that Bastian Jans Krol (1596-1674) was guilty of premarital sex with a wife of his on two occasions. In an essay on Everardus Bogardus (1607-1647), Frijhoff relates that the predikant battled the bottle and his temper and lost on both counts. Laurentius vanden Bosch (c. 1660?-1696), in Evan Haefeli's essay, gained notoriety for swearing profusely, getting drunk, molesting women, beating his wife, and denouncing anyone who dared call him to account. Most Reformed ministers in these essays fell between these two extremes, but almost all of them endured financial hardship, immigrated because of the tight ecclesiastical job market in the Netherlands, moved frequently, quarreled regularly, and possessed an outsized appreciation of their own importance.

Several essays warrant special attention. Frijhoff does a masterful job explaining the complex personality of Bogardus; Van der Linde's essay on Selijns offers clear insight into the stresses that the Glorious Revolution wrought on Dutch congregations; Goodfriend's treatment of Laidlie illustrates how ministers could self-fashion according to their environment; and Haefeli provides an entertaining rollick with the wacky Vanden Bosch. One common problem that most authors faced was the spotty and meager documentation about their subjects. Edward William Kennedy lacked any sources for the last twenty five years of Giulam Bertholf's (1656-1727) ministry in New Jersey and New York. Similarly, the absence of sources compelled Leon van den Broeke to speculate on the reasons that Rudolphus van Varick (1645-1694) left his pastorate at the small village of Hem (in North Holland) rather quickly for a post in America. To their credit, the authors are forthright about the limitations of their sources, though the sparse documentation often raises more questions than they answer. Transatlantic Pieties will prove most useful 
to those interested in the Dutch Reformed influence in North America in the early modern period.

Charles H. Parker, Saint Louis University 
Nadia Bouras, Het land van herkomst. Perspectieven op verbondenheid met Marokko, 1960-2010 (Dissertatie Leiden 2012, Historische migratiestudies 3; Hilversum: Verloren, 2012, 300 pp., ISBN 978908704323 0).

'Het land van herkomst', de gepubliceerde versie van het proefschrift van historica Nadia Bouras, maakt deel uit van een steeds groter wordende historiografie die verschillende aspecten van de naoorlogse migratie naar West-Europa bestrijkt. Een tiental jaar geleden waren nog maar weinig historici bezig met dit onderwerp; nu verschijnen steeds meer studies waarin de migratie van 'gastarbeiders' uit de landen rond het Middellandse Zeegebied vanuit een historisch oogpunt wordt geanalyseerd. Jammer genoeg krijgt deze nieuwe golf van studies weinig aandacht in het historiografisch overzicht van de auteur, dat zich focust op de sociologische en antropologische literatuur die sinds de jaren zeventig over deze groep verscheen (18-21). Dit hangt samen met de eerder eenzijdige focus van de auteur op de Marokkaanse casus in Nederland. Vergelijkingen met andere Europese landen of andere groepen in Nederland komen in de inleiding nauwelijks aan bod en door het boek heen slechts terzijde. Dit is jammer, want een breder perspectief had duidelijk kunnen maken welke de specificiteiten en de eerder algemene kenmerken zijn van de Marokkaans-Nederlandse casus. Bouras belooft echter geen internationale vergelijkingen, maar een goed uitgewerkte casus, en die bezorgt ze ook.

Centraal in dit boek staan de banden van Marokkaanse immigranten in Nederland met hun land van herkomst. Er wordt gekeken naar wat die banden precies inhielden voor organisaties en individuen, welke factoren hun ontstaan en verandering door de tijd heen beïnvloedden, en wat de houding was van sturende en ontvangstlanden ten opzichte van deze banden. De onderzochte tijdsspanne, een halve eeuw, laat toe de verschuivingen in banden en het debat erover te volgen; grote structurele veranderingen (zoals de crisis vanaf het midden van de jaren 1970) en hun invloed worden goed geduid.

Het boek is onderverdeeld in negen hoofdstukken. In het eerste hoofdstuk, de inleiding, legt Bouras uit wat de centrale thematiek en de onderzoeksvragen van het boek zijn, en geeft ze de opbouw van het boek aan. In het tweede hoofdstuk behandelt ze het concept 'transnationalisme' en het gebruik ervan in het academische debat. Het derde hoofdstuk verschaft de lezer een inzicht in de geschiedenis van de Marokkaanse 
migratie naar Nederland aan de hand van data, cijfergegevens, foto's en persoonlijke verhalen.Het eigenlijke onderzoek naar de banden van Nederlandse Marokkanen met hun land van herkomst komt aan bod in het vierde tot en met negende hoofdstuk van het boek.

Eerst behandelt Bouras de houding van respectievelijk het ontvangst- en herkomstland ten aanzien van die banden. In hoofdstuk vier worden de perspectieven en invloed van de Nederlandse overheid en publieke opinie, onderzocht aan de hand van een indrukwekkende collectie beleidsdocumenten en krantenknipsels, uit de doeken gedaan. Hier wordt beschreven hoe Nederland eerst de banden van Marokkanen met het herkomstland aanmoedigde, later de nadruk legde op het behoud van de eigen cultuur, en tenslotte, vanaf de jaren negentig, banden met het land van herkomst ging ontmoedigen. Hoofdstuk vijf bekijkt de banden van Marokkanen met hun herkomstland vanuit het perspectief van Marokko en toont hoe het Marokkaanse beleid naar emigranten toe veranderde van een 'lange arm' naar een 'uitgestoken hand'. In tegenstelling tot hoofdstuk vier is dit hoofdstuk gebaseerd op secundaire literatuur, eerder dan op bronnenonderzoek. Het heeft dan ook heel wat minder om het lijf (ook in omvang, 20 in plaats van 50 pagina's).

In hoofdstuk zes springt Bouras van het macro- naar het meso-niveau en behandelt ze de banden die Marokkaanse organisaties in Nederland onderhielden met Marokko. Het hoofdstuk wordt chronologisch onderverdeeld in een eerste (1974-1994) en een tweede (1994-2010) deel. Bouras focust op vier organisaties, de Amicales des Travailleurs et Commerçants Marocains en het Komitee Marokkaanse Arbeiders in Nederland in de eerste periode, de Unie van Marokkaanse Moskeeorganisaties in Nederland en het Nederlands Centrum Buitenlanders in de tweede periode, die elk op hun eigen manier banden met het land van herkomst onderhielden.

In hoofdstukken zeven, acht en negen verlegt Bouras opnieuw de focus, ditmaal naar het micro-niveau, naar de banden van individuele Marokkanen (mannen en vrouwen) met het land van herkomst. De onderverdeling is van chronologische aard (1960-1973 / 1973-1985 / 1985-2010). De individuele banden van Marokkanen met het thuisland worden beschreven als variabel naargelang het individu en veranderlijk door de tijd heen. Gender, klasse, leeftijd en andere verschillen hadden hun weerslag, alsook wijzigingen in de houding van het ontvangst- en herkomstland - zoals beschreven in de hoofdstukken vier en vijf - en structurele veranderingen in de sociaal-economische, culturele en politieke situatie van de betrokkenen - de enorme impact van de grote werkloosheid vanaf de jaren tachtig wordt hier als voorbeeld gegeven. In tegenstelling tot de voorgaande hoofdstukken, zijn de hoofdstukken zeven, acht en negen vooral op basis van mondelinge bronnen opgebouwd. Sommige paragrafen krijgen hierdoor echter een erg anekdotisch karakter, zoals het stukje ‘Naar Marokko' (192) en 'Geldovermakingen' (194), waarbij aanvullende gegevens (bijvoorbeeld cijfergegevens over het aantal jaarlijkse oversteken, gegevens over de geldovermakingen, et cetera) het onderzoek een bredere 
basis zouden geven. Toch zijn deze hoofdstukken interessant en bieden ze veel nieuwe informatie.

In de eindconclusie van het boek vat Bouras de conclusies van de drie delen op een overzichtelijke manier samen en verbindt deze met elkaar. Vooral de complexe wisselwerking van structuur en agency, en de impact van verschillen tussen individuen en groepen mensen in de constructie en continuïteit van banden met het herkomstland worden in de verf gezet.

Het land van herkomst is een rijk gestoffeerd boek, dat de geschiedenis van de naoorlogse migratie naar West-Europa vanuit een vernieuwende invalshoek, die van de banden van migranten met het land van herkomst, bekijkt. Heel sterk is de combinatie van macro-, meso- en microperspectief, waarbij de centrale thematiek vanuit het standpunt van zowel overheden, organisaties als individuen wordt bekeken, alsook het empirisch onderzoek, zowel op basis van geschreven als mondelinge bronnen, dat aan de basis van het werk ligt. Hoewel de genderproblematiek niet zo afwezig is in het migratieonderzoek als Bouras aangeeft (13), valt het werk op door zijn consistente aandacht voor gender, opnieuw met een solide basis - zo zijn meer dan de helft van de geïnterviewden vrouwen, iets wat zelden voorkomt in migratieonderzoek dat niet specifiek over vrouwen gaat.

Minder sterk is het betoog binnen de afzonderlijke hoofdstukken van het boek, dat niet altijd even duidelijk is. Als lezer verlies je nogal vaak de draad van het verhaal, door de vele anekdotes die het betoog doorspekken - deze zijn op zich wel interessant, maar vaak onnodig. Dit is bijvoorbeeld het geval in hoofdstuk drie, waar sommige persoonlijke verhalen niet op hun plaats lijken te staan, en in hoofdstuk zeven (bijvoorbeeld 189-190), acht (bijvoorbeeld 210-211), en negen (bijvoorbeeld234-235), waar onnodige details ervoor zorgen dat de flow van het verhaal in het gedrang komt.

De consistentie waarmee Bouras de rode draad van haar verhaal dan toch weer oppikt, door in de inleiding en conclusie van elk hoofdstuk vraagstelling en samenvatting van de onderzoeksresultaten kernachtig te bundelen, maakt veel goed. Verder zorgen de vele details en anekdotes, alsook het rijke beeldmateriaal, er wel voor dat het boek aangenaam is om te lezen, en ook een breder publiek zal kunnen bekoren. Dit is goed, want het werk heeft een wijdere dan enkel academische relevantie. Het tackelt een actueel onderwerp door het historisch te kaderen, op basis van een uitgebreid en degelijk empirisch onderzoek. Het is dan ook een aanrader voor iedereen die zich met migratie- en integratievraagstukken bezighoudt.

Jozefien De Bock, European University Institute 
Bruno Benvindo en Evert Peeters, Scherven van de oorlog. De strijd om de herinnering aan de Tweede Wereldoorlog 1945-2010 (Antwerpen: De Bezige Bij, 2011, 260 pp., ISBN 97890 $85423249)$.

De historici Bruno Benvindo en Evert Peeters schreven een mooi boek over de sociale herinnering aan de Tweede Wereldoorlog in België. Of beter gezegd, over de pijnlijke strijd die de verschillende betrokkenen hiervoor sindsdien tot op de dag van vandaag met elkaar voeren. Want die herinnering aan de jaren 1940 -1945 was allesbehalve eenduidig. België zou volgens de socioloog Luc Huyse 'ziek van zijn jaren veertig' zijn, of er toch tenminste een groot 'verdriet' aan overhouden, zoals Hugo Claus in zijn roman suggereerde (zie Luc Huyse, 'Waarom België ziek is van zijn jaren veertig', Bijdragen tot de Eigentijdse Geschiedenis 10 (2002) 185-193; Hugo Claus, Het verdriet van België (Amsterdam 1983)).

Scherven van de oorlog vertrekt vanuit de gedachte dat er - net als in andere (West-) Europese landen - in België geen gedeelde herinnering aan de Tweede Wereldoorlog bestaat. In plaats daarvan bestaan er meerdere herinneringsgemeenschappen die de afgelopen decennia onderhandelden over de duiding van dit verleden. De auteurs proberen deze onderhandelingsprocessen in kaart te brengen aan de hand van vier gedenkplekken (lieux de mémoire): het gevangenkamp Fort van Breendonk, de Congreskolom in Brussel, de IJzertoren in Diksmuide en de Dossinkazerne in Mechelen.

De strijd om de herinnering wordt al snel duidelijk in de bespreking van het voormalige gevangenkamp Breendonk dat na de oorlog uitgroeide tot het ultieme symbool van de Duitse repressie. De Belgische regering voerde lange tijd geen beleid om de herinnering hieraan levend te houden, maar gaf in plaats daarvan de slachtoffers zelf ruimte om dit vorm te geven. Maar juist door de afwezigheid van een centraal beleid, vlogen de oud-politieke gevangenen elkaar dikwijls in de haren over de invulling van die herinnering, bijvoorbeeld wanneer het ging om de plek van de communistische gevangenen. Desondanks groeide onder invloed van de agency van deze oud-politieke gevangenen Breendonk uit tot een centrum van het Belgisch patriottisme. Dat veranderde toen een sterker wordend mensenrechtendiscours er in de jaren zeventig voor zorgde dat meer groepen slachtoffers aanspraak op de plek maakten, zoals Joden 
en homo's. Bovendien ging een nieuwe generatie 'de gruwel van Breendonk' in verband brengen met hedendaagse repressieve regimes. Dit tot ongenoegen van de oud-politieke gevangenen die Breendonk alleen als een patriottistisch monument wilde zien.

Net als Breendonk fungeerde ook de Congreskolom in Brussel (het Graf van de onbekende soldaat) als een monument van 'goed' vaderlanderschap. Anders dan bij Breendonk werd deze herinnering ingebed in de bestaande patriottistische herinnering aan de Eerste Wereldoorlog. Hier werd gedroomd van de eenheid van het land. Herhaling van fascisme kon in de toekomst alleen worden voorkomen via eendracht, zo klonk het. De uitsluiting van de voormalige communistische verzetslieden, de polariserende Koningskwestie en het oprukkende federalisme zorgde vanaf de jaren zestig echter voor ontgoocheling bij deze 'ware' Belgen. Er diende zich geen nieuwe generatie aan die de plek gebruikte voor haar herinnering aan de oorlog en de Congreskolom raakte als gevolg hiervan in de vergetelheid.

Hoe anders verging het de IJzertoren in Diksmuide. Deze plek groeide uit als tegenpool van Breendonk en de Congreskolom. Hier werden geen Belgische, maar Vlaams-nationalistische helden geëerd. Na de oorlog had de Belgische regering tevergeefs geprobeerd om van de IJzertoren een gedeeld verleden te maken. De Vlaamsnationalistische herinneringsgemeenschap slaagde er echter in om van de IJzertoren het symbool van de collaboratie te maken. Dit werd de plek waar de naoorlogse 'repressie' ter discussie werd gesteld. De auteurs benadrukken niet genoeg dat het Belgische herinneringsparcours op dit punt behoorlijk afwijkt van de rest van West-Europa. Een fenomeen als de IJzertoren en de bijbehorende herinneringsgemeenschap was bijvoorbeeld in het Nederland van na de Tweede wereldoorlog ondenkbaar.

Interessant is hoe vanaf de jaren tachtig, onder invloed van de toenemende federalisering, de Vlaamse overheid de IJzertoren gebruikte voor de legitimatie van haar zelfstandig bestaan. Het moest een symbool van alle Vlamingen worden, ontdaan van alle radicale elementen. De greep van de collaboratieherinnering verzwakte volgens auteurs als gevolg hiervan. Hierbij wordt niet verder uitgewijd over de rol van de media of de rol van een nieuwe Vlaamse generatie historici die tegen deze tijd brak met de traditie om de Vlaams-nationalistische collaboratie te vergoelijken. De opkomst vanaf de jaren tachtig van een nieuw racistisch en rechts-radicaal Vlaams-nationalisme had hier alles mee te maken. De groeiende belangstelling voor de Jodenvervolging die in België eigenlijk pas vanaf de jaren tachtig op gang kwam, zorgde er daarnaast voor dat de collaboratie kritischer tegen het licht werd gehouden.

Die aandacht voor de Jodenvervolging wordt in het laatste hoofdstuk over de Dossinkazerne behandeld. Hier zien we hoe de Jodenvervolging in België pas recent uitgroeide tot het symbool bij uitstek van de Tweede Wereldoorlog - nog zo'n punt waarop België internationaal gezien behoorlijk afweek. In de eerste periode na de oorlog werd de Joodse herinnering aan de oorlog ingepast in het dominante discours van heldenmoed en patriottistische strijd. De Mechelse Dossinkazerne, waar vanuit meer dan 25.000 Joden en Roma werden gedeporteerd paste als symbool niet in dit discours en 
kreeg na de oorlog direct een andere bestemming. Eerst diende het als militaire kazerne en later werden er luxe appartementen ingebouwd. In de jaren negentig begon de Vlaamse overheid zich met de Dossinkazerne te bemoeien en wilde van deze 'vergeten' plek een belangrijk gedenkteken maken. Ook hier lag het nieuw racistisch en rechtsradicaal Vlaams-nationalisme aan de basis van de herontdekking van de plek. Via Holocausteducatie zou de Vlaamse overheid de burger op deze plek alert moeten maken voor de gevolgen van (politiek) extremisme.

In de behandeling van de plekken laten de auteurs overtuigend zien dat meerdere partijen over de jaren heen met elkaar in de clinch raakte over de duiding van het verleden. De Belgische overheid speelde hier lange tijd nagenoeg geen rol bij. Pas op het moment dat de Belgische staat steeds verder verbrokkelde, begon de Vlaamse overheid de plekken te gebruiken ter legitimering van haar bestaan. Een van de vragen die achterblijft na lezing van het boek is welke scherven van de oorlog er in Wallonië bestaan. Kende de Waalse Beweging dan geen herinneringsgemeenschap met bijbehorende plekken? Dit komt in het boek niet ter sprake, wat er misschien op wijst dat dit een beduidend minder belangrijke plek in de oorlogsherinnering achter liet. Tot slot moet worden opgemerkt dat dit boek werd geschreven in opdracht van het federale Studie- en Documentatiecentrum voor Oorlog en Hedendaagse Maatschappij (SOMA). De gefragmenteerde herinnering aan de oorlog wordt door de Franstalige Benvindo en Nederlandstalige Peeters vanuit het bredere Belgisch perspectief bestudeerd. Dat geeft dit boek een grote meerwaarde.

Helen Grevers, NIOD Instituut voor Oorlogs-, Holocaust- en Genocidestudies 


\section{John Exalto, Wordt een heer! Kweekschool De Driestar en de emancipatie van de}

bevindelijk gereformeerden (Heerenveen: Groen, 2012, 520 pp., ISBN 978908897049 8).

'De universiteit van de SGP', zo karakteriseerde freule Wttewaal van Stoetwegen ooit de pedagogische academie De Driestar in Gouda. Niet onterecht: heel wat kader uit de bevolkingsgroep achter de Staatkundig Gereformeerde Partij, de bevindelijk gereformeerden, bezocht ooit De Driestar. John Exalto beschrijft in 'Wordt een heer!' uitgebreid de ontstaansgeschiedenis van de kweekschool, de stichter ervan en de religieuze en pedagogische context. Bij de religieuze context gaat de meeste aandacht naar het kerkverband van de Gereformeerde Gemeenten, waarvan stichter Pieter Kuijt (1910-1987) lid was. Exalto onderscheidt een fase van dogmatisering van 1910 tot 1948, een van pedagogisch ontwaken van 1948 tot 1975 en een van professionalisering sinds 1975. Alleen de twee eerste fasen worden in dit boek beschreven. De oprichting van de onderwijzersopleiding, in september 1944 in het Zeeuwse Krabbendijke, valt er middenin.

'Wordt een heer!' lijkt omvangrijker dan het in werkelijkheid is: de hoofdtekst eindigt op bladzijde 395 en het boek is in een vrij grote letter gedrukt. Soms is het wat wijdlopig, met bijvoorbeeld een overbodige uitweiding over de naamgeving van scholen in het algemeen (175-176) en een moeilijk te volgen stuk over de moeite die Kuijt had om zijn lesbevoegdheid (MO-A) te halen (270-276). Desalniettemin heeft Exalto een waardevolle bijdrage geleverd aan onze kennis van de betreffende bevolkingsgroep en haar emancipatie die met name in de tweede helft van de twintigste eeuw plaatsvond.

Die emancipatie werd voorbereid door de 'etnisering' van de bevindelijk gereformeerden, in eerste instantie met name de leden van de Gereformeerde Gemeenten, waarbij het streven van kerkleider en SGP-oprichter ds. G.H. Kersten (18831948) in de periode 1910-1930 sturend en bepalend was. Kersten keek van Kuyper diens methodes af: lokaal isoleren, nationaal organiseren. Op onderwijsgebied betekende dat de stichting van tientallen eigen lagere scholen - in 1933 bepaalde een Koninklijk Besluit dat de Gereformeerde Gemeenten in dit opzicht als een eigen richting mochten gelden. In 1968 waren uit dit streven 6 ULO's, 54 lagere scholen en 14 kleuterscholen voortgekomen. Dit 'scholennetwerk' bevorderde sterk de vorming van een eigen volksdeel.

Kuijt was hoofd van de lagere school van de Gereformeerde Gemeente te Krabbendijke en stichtte zijn onderwijzersopleiding ongeveer gelijktijdig met de ULO die hij aan zijn school wist te verbinden. Het was behelpen, het was kleinschalig, maar het 
voldeed in een behoefte. Beide waren trouwens interkerkelijk, in elk geval wat betreft de leerlingen die er op afkwamen. Maar Kuijts streven om een protestants-christelijke ULO voor oostelijk Zuid-Beveland en een dito kweekschool van de grond te krijgen, stuitte af op het bestuur van de lagere school. Dit was samengesteld uit leden van de plaatselijke Gereformeerde Gemeente die geen interkerkelijke school wensten. Niet-leden van het kerkverband trokken zich na verloop van tijd uit het ULO-bestuur terug. Pas in Gouda, waarheen Kuijt en de kweekschool in 1954 na de Watersnoodramp verhuisden, werd de school weer interkerkelijk - zoals de stichter zelf altijd gewild had. Dit keer werd de beproefde SGP-formule gehanteerd: een meerderheid van de bestuursleden uit de Gereformeerde Gemeenten, geflankeerd door enerzijds behoudende hervormden en christelijke gereformeerden en anderzijds door leden van de nog kleinere en nog radicalere kerkverbanden. De formule werkte prima, van onenigheid was amper sprake.

Vanaf de jaren zestig werkte Kuijt een eigen pedagogiek uit. Exalto noteert als opmerkelijk, althans voor deze kringen, dat daaraan niét een pessimistisch mensbeeld ten grondslag lag. Kuijts opvoedingsvertoog was 'volop eigentijds' (323). Op De Driestar werd wel de eigen levensovertuiging overgedragen, maar toch ook discussie bevorderd en groepswerk gepraktiseerd. De trek van studenten naar De Driestar was voor hen vaak op zich al een doorbreking van het normenpatroon dat in hun woonplaats gold (395). Exalto noemt de bevindelijk gereformeerden 'verliezers' van het moderniseringsproces 'omdat zij de omringende samenleving steeds verder af zagen glijden van een Gode welgevallige levensorde' (38). Dat laatste was natuurlijk vooral het beeld dat Kersten optrok, bijvoorbeeld als SGP-er in de Tweede Kamer - in dezelfde decennia waarin hij zijn achterban mobiliseerde. Exalto verdisconteert hier te weinig hoe Kersten scheidslijnen trok die eerder nooit bestaan hadden. Elders blijkt de auteur zich hiervan wel bewust te zijn en spreekt hij van 'soms nodeloze segregatie' (59). Zeker in Zeeland was in het Interbellum geen heel duidelijk verschil tussen bevindelijk gereformeerden en anderen als het ging om het moderniseringsproces. Dat Exalto niet goed thuis is in de onderhavige periode blijkt ook als hij meent dat de notulen van de Krabbendijkse gemeenteraad en burgemeester en wethouders ‘in de loop van 1941 niet meer werden bijgehouden' (124). Dat de bezetters de raden en het wethouderschap per 1 september 1941 afschaften, weet hij blijkbaar niet. Of werd er al voor 1 september niet meer genotuleerd? Evenmin geeft Exalto er blijk van te weten dat Kersten na de oorlog niet alleen uit de Tweede Kamer gezet werd vanwege defaitistische schrijverij op godsdienstige gronden (135), maar ook vanwege verzoeken aan de Duitsers om opdrachten voor de persen van zijn uitgeverij. Kerstens waarschuwing tegen eenheidsstreven in de politiek was niét gericht tegen de Nederlandse Volksbeweging (210), maar tegen het gelijktijdige (getorpedeerde) streven naar meer eenheid tussen de Antirevolutionaire Partij, de Christelijk-Historische Unie en de Staatkundig Gereformeerde Partij.

Exalto lijkt op meer punten in het boek zich te weinig rekenschap te geven van de samenleving waarbinnen de segregatie en de emancipatie van de bevindelijk gereformeerden zich voltrok. Nergens vermeldt hij dat de arbeiders en kleine boeren uit 
dit milieu tot aan de Tweede Wereldoorlog de luttele verdiensten van hun oudere kinderen hard nodig hadden en hen om die reden niet lieten doorleren. Zoons van grotere boeren leerden juist weer het vak in de praktijk, met hooguit een landbouwcursus. Dat er een 'mentaliteitsverandering' nodig was ten aanzien van 'kennis en scholing' (161), is dus maar een deel van het verhaal.

Exalto wordt beslist anachronistisch waar hij een tegenstelling creëert tussen de steun van de Oud-Gereformeerde predikant W.H. Blaak voor De Driestar en diens aanhangen van de ledeboeriaanse principes (281). In de tijd van ds. L.G.C. Ledeboer (18081863) was de situatie ten aanzien van onderwijs onvergelijkbaar met die van honderd jaar later. Ledeboers principes verwezen naar de verhouding tussen kerk en staat zoals die was vóór 1795 en vatten de Hervormde Kerk op als het eigenlijke thuis van de bevindelijk gereformeerden - hen was alleen de toegang ertoe ontzegd. Bij Exalto krijgt deze heel specifieke ideologie echter, ten onrechte, de lading van behoudendheid zonder meer en verandert 'ledeboeriaans' van een strikt kerkhistorische aanduiding voor een ideologie in een soort sociologische term. Zo kan Exalto de hervormde theoloog I. Kievit 'beslist geen bevindelijke ledeboeriaan' noemen (196), maar dat is ongerijmd. Voor een hervormde was (is) een al dan niet ledeboeriaanse visie - die altijd existentieel beleefd werd irrelevant. Ook wanneer Exalto 'de ledeboeriaanse traditie in de Gereformeerde Gemeente' aanwijst als één van de bronnen voor gewetensbezwaren tegen vaccinatie (52), is dat niet geheel terecht. Recent onderzoek laat zien dat dit met name gold voor één van de richtingen onder de ledeboerianen, de volgelingen van oefenaar D. Bakker.

Jan Zwemer, Serooskerke 
Aline Sax, Voor Vlaanderen, Volk en Führer. De motivatie en het wereldbeeld van Vlaamse collaborateurs tijdens de Tweede Wereldoorlog 1940-1945 (Antwerpen: Manteau, 2012, 422 pp., ISBN 9789022327517 ).

Voor veel Nederlandse historici die zich verdiepen in de Nederlandse oorlogsjaren (19401945) vormt het bezette België interessant vergelijkingsmateriaal. Nederland en België werden in de meidagen van 1940 bijna gelijktijdig overrompeld door een Duitse militaire overmacht. In Nederland hield het eigen leger vier dagen stand, in België achttien dagen. Wat volgde waren vier (in België en Nederland beneden de grote rivieren) tot vijf (in de rest van Nederland) jaren van bezetting. In die periode voerde een Duits bezettingsbestuur het bewind dat in beide landen was samengesteld uit grofweg dezelfde hoofdbestanddelen: ordehandhaving, oppositiebestrijding, economische exploitatie, jodenvervolging en nazificatie. Voor de uitvoering van dat bewind waren de Duitse autoriteiten in hoge mate aangewezen op de meebuigzaamheid van inheemse elites en de steun van individuele burgers. Collaboratie - op verschillende niveaus en in verschillende maten - vond in beide landen plaats.

Het is niet verwonderlijk dat er voor dit gevoelige thema zowel in de Belgische als de Nederlandse oorlogsgeschiedschrijving de nodige aandacht bestaat, maar de ontwikkeling van die geschiedschrijving sinds de bevrijding loopt in beide landen sterk uiteen. Waar in naoorlogs Nederland het bestaan van collaboratie lange tijd werd afgedaan als een maatschappelijk randverschijnsel en als het verwerpelijke werk van een betrekkelijk klein groepje 'landverraders', was er in België - en dan vooral Vlaanderen na de oorlog veel minder sprake van maatschappelijke veroordeling en uitsluiting. De (al dan niet vermeende) voortdurende achterstelling van Vlamingen in de relatief jonge Belgische staat had Vlaamse jongelingen in de armen van de Duitsers gedreven. In de vroege Belgische geschiedwerken werd vooral de naoorlogse behandeling van collaborateurs aan de kaak gesteld: het straatgeweld tegen hen in de bevrijdingsdagen, hun leed in naoorlogse detentie en de misstanden in naoorlogse vervolging en berechting. Al deze zaken werden samengevat als 'repressie' en dat is, heel veelzeggend, ook de bij onze zuiderburen gebruikelijke aanduiding van de officiële bestraffing van collaborateurs. Zij omsloeg een keur aan strafmaatregelen: de openbare auditeur (aanklager) kon iemand 'epureren', wat feitelijk de beroving van enkele of alle burgerrechten betekende; 
de burgemeester kon een verdachte het bewijs van burgertrouw onthouden, wat onder andere inschrijving in het handelsregister of aan de universiteit blokkeerde; en de (militaire) rechter kon een straf opleggen. In de naoorlogse jaren zijn in België naar schatting 400.000 dossiers aangelegd van personen op wie de verdenking rustte misdaden en wanbedrijven tegen de veiligheid van de staat te hebben begaan (artikel 113 tot 123 van het Belgische Strafwetboek). In 57.254 van die zaken kwam het tot een aanklacht. Hiervan leidden 53.000 ook daadwerkelijk tot een veroordeling.

Aline Sax heeft voor haar proefschrift, waarvan Voor Vlaanderen, Volk en Führer de handelseditie is, gretig gebruik gemaakt van de rijkdom van deze repressiedossiers. Deze bevatten uiteraard de juridische stukken betrekking hebbende op de rechtsgang, maar dikwijls ook allerhande documenten die als bewijsmateriaal moesten dienen: brieven en foto's uit de oorlogstijd, lidmaatschapskaarten van Duitsgezinde organisaties; getuigenverklaringen na de oorlog, en dergelijke. Hoewel op grond van de dossiers een fraaie reconstructie van de repressie mogelijk zou zijn, ligt Sax' ambitie elders: zij beoogt te achterhalen wie de 'gewone' Vlaamse collaborateurs waren, waarom zij collaboreerden en hoe zij zichzelf en de wereld om zich heen zagen. Een selectie van maar liefst 326 dossiers ligt aan haar onderzoek ten grondslag.

Dit knappe kwantificerende pionierswerk bevestigt oude, maar levert ook nieuwe inzichten op. Zo toont Sax overtuigend aan, dat collaboratie vooral een aangelegenheid was van jongemannen uit de lagere sociale klassen. Opvallend is bovendien het hoge percentage van verdachten dat al lang vóór de oorlog lid was geworden van een van de bewegingen die in oorlogstijd met de Duitsers heulden (met name het Vlaams Nationaal Verbond). Volgens de auteur was bijna de helft van alle collaborateurs ideologisch gemotiveerd. De indruk dat het bij deze 'gewone' collaborateurs om gedreven nationaalsocialisten ging, wordt ook in Sax' discours-analyse bevestigd. Talloze brieven, geschreven in oorlogstijd, zijn hiervoor bekeken. Het wereldbeeld dat uit die brieven naar voren komt, strookt volkomen met het wereldbeeld dat het nationaal-socialisme verkondigde. Men had sterke vijandbeelden, men voelde zich Vlaams én Germaan, men beschouwde het als zijn plicht om zich in te zetten.

Voor wie van kinderboeken houdt, is Aline Sax geen onbekende: Sax heeft een uitgebreid oeuvre aan historische romans op haar naam staan. Het besproken boek laat het literaire talent van de auteur zien, maar toont evenzeer Sax als een uitstekend onderzoeker. Haar bronnenverantwoording van ruim twintig bladzijden is voorbeeldig. Toch is het juist dat bronnengebruik waarbij ik een bescheiden kanttekening zou willen plaatsen. Wie de 'gewone' collaborateurs waren - de eerste hoofdvraag in het onderzoek - is eenvoudig uit de repressiedossiers te destilleren: hier gaat het om personalia. Het is echter de vraag of het repressiedossier - en dan met name de correspondentie uit de oorlogsjaren - ook de meest aangewezen plaats is om de motivatie en het wereldbeeld van de betrokkene te achterhalen. Hoe eerlijk en openhartig is iemand over zijn beweegredenen en opvattingen als hij eenmaal aan het front ligt en zijn post onderworpen is aan censuur? In hoeverre bauwt hij niet simpelweg 
de hem voorgeschotelde propaganda na of probeert hij niet met stoere praat over militaire plicht en de goede zaak het thuisfront (en wellicht ook zichzelf) een hart onder de riem te steken? Is deze groep van naar huis schrijvende mannen representatief en inderdaad 'gewoon'? Het zijn twijfels die deze bronnen naar mijn mening niet helemaal kunnen ontzenuwen. Wellicht kan aanvullend onderzoek, waarin ook ander bronnenmateriaal wordt betrokken (dagboeken, correspondentie en ledenadministratie van bijvoorbeeld het Vlaams Nationaal Verbond of de Waffen-SS), ons hier verder helpen.

Geraldien von Frijtag Drabbe Künzel, Universiteit Utrecht 